\title{
Długi wiek XIII - początki krzyżackiej murowanej architektury obronnej na ziemi chełmińskiej w świetle najnowszych badań
}

\section{The long $13^{\text {th }}$ century - the beginnings of the Teutonic Order defensive masonry architecture in Chelmno Land in light of recent research}

Zarys treści. Problematyka badań archeologiczno-architektonicznych zamków krzyżackich jest od wielu lat przedmiotem ożywionych studiów i badań, ale do tej pory - z różnych względów - nie doczekała się całościowego podsumowania. W artykule przedstawiono najnowsze podsumowanie wyników badań kilku zamków krzyżackich ziemi chełmińskiej - w Papowie Biskupim, Radzyniu Chełmińskim, Wąbrzeźnie, Grudziądzu i Kowalewie Pomorskim - prowadzonych przez Instytut Archeologii UMK w Toruniu.

Słowa kluczowe: ziemia chełmińska; zamki krzyżackie; badania archeologiczno-architektoniczne; historia architektury; archeologia.

Zamki wzniesione przez zakon krzyżacki na ziemi chełmińskiej stały się jednym z najbardziej charakterystycznych elementów krajobrazu. Pełniły one różną funkcję, realizowały cele polityczne, militarne, gospodarcze i propagandowe. Stały się widomym świadectwem dobrze zorganizowanego państwa.

Od wielu lat podejmowane są próby całościowego spojrzenia na tę problematykę. Jednak historycy, historycy sztuki, historycy architektury, archeolodzy zwracali uwagę na niedostateczny stan badań, które, mimo że realizowane od blisko 200 lat, prowadzone były w różnych okresach przez doświadczonych badaczy, ale często również przez zupełnie do tego nieprzygotowanych urzędników, rekonstruktorów, amatorów bądź nawet hobbystów, bardziej wyobrażających sobie, jak powinny one wyglądać niż jak w rzeczywistości wyglądały. W związku $\mathrm{z}$ tym stan naszej wiedzy jest nierównomierny. Mimo znacznego zaangażowania 
badawczego, zwłaszcza w ostatnich 30 . latach, w dalszym ciągu szereg istotnych dla zrozumienia tego fenomenu kwestii, często o fundamentalnym znaczeniu, nie jest dostatecznie udokumentowanych czy rozpoznanych. Dotyczy to szczególnie takich problemów jak chronologia kolejnych etapów prac budowlanych, topografia i układ przestrzenny zamków, funkcja poszczególnych elementów zabudowy oraz rozpoznanie śladów osadnictwa przedkrzyżackiego, poprzedzającego prace budowlane. Zresztą sposób wznoszenia w średniowieczu zamków w Prusach, a co za tym idzie także w ziemi chełmińskiej, mimo podejmowanych przez kilku uczonych prób jego rozpoznania, wymaga korekt i weryfikacji. Szczególnie jest to istotne w kontekście badań z ostatnich lat, dotyczących chronologii, topografii i układu przestrzennego zamków krzyżackich w Prusach na podstawie średniowiecznych źródeł pisanych (zwłaszcza Jóźwiak, Trupinda 2011; 2012), które w paru istotnych aspektach przynoszą nowy materiał porównawczy. Ważnym problemem są też kwestie dotyczące wzajemnych relacji między efektem aktywności budowlanej a środowiskiem przyrodniczym w skali lokalnej i ponadregionalnej. Niektóre z nich stały się ostatnio elementem rozważań i poszukiwań (Jóźwiak, Trupinda 2011; 2012; Pluskowski 2012), inne, zwłaszcza związane z chronologią i charakterem układów przestrzennych, w dalszym ciągu czekają na wyjaśnienie.

Celem badań podjętych w 2005 roku przez Zakład Archeologii Architektury Instytutu Archeologii Uniwersytetu Mikołaja Kopernika w Toruniu była próba odpowiedzi na podstawowe pytania związane z początkami krzyżackiej murowanej architektury obronnej na ziemi chełmińskiej, a więc szczegółów budowy, topografii, układu przestrzennego zamków. Niezmiernie ważną kwestią jest określenie początków aktywności budowlanej: czy miała ona miejsce już w latach 50. XIII stulecia, czy też - jak na to wskazują ostatnie studia historyczne - dopiero w ostatnich 30. latach XIII lub w początkach kolejnego wieku. Istotne jest też, czy obiekty te powstawały według dotychczas przyjmowanego modelu: od układów drewnianych, potem murowanych, nieregularnych (Rogoźno, Lipienek), do form regularnych (czworobocznych) charakterystycznych dla tzw. zamków konwentualnych. W związku z tym powstaje pytanie, jaka była geneza i forma najstarszych zamków krzyżackich i czy wznoszono je według przygotowywanych wcześniej planów lub modeli, co ostatnio w nauce zdaje się być kwestionowane (Jóźwiak, Trupinda 2012). Warto też zastanowić się nad kwestią lokowania zamków krzyżackich; jak sugerują niektóre przekazy źródłowe wznoszono je na wcześniejszych osadach obronnych (pruskich, słowiańskich; np. w Grudziądzu), z kolei wyniki badań archeologicznych przeprowadzonych na niektórych obiektach (np. Papowo Biskupie) świadczą o tym, że powstawały w miejscach do tej pory niezasiedlonych (m.in. Poliński 2003, s. 181-196; 2007a, s. 155-178; 2007b, s. 241-257). 
Omawiając długi wiek XIII w kontekście początków krzyżackiej murowanej architektury obronnej na ziemi chełmińskiej nie będziemy prezentować szczegółowego stanu badań. Warto jednak przypomnieć najważniejsze - naszym zdaniem - dotychczasowe opracowania dotyczące charakterystyki i chronologii rozwoju tej formy architektury.

Spośród badaczy niemieckich dwóch zasługuje na szczególną uwagę - Karl Heinz Clasen i Bernhard Schmid. Pierwszy z wymienionych to autor jednej z ważniejszych prac o zamkach państwa zakonnego, w której omówił genezę, przebieg rozwoju oraz czynniki wpływające na taki, a nie inny obraz architektury zamkowej. Jej rozwój zawarł w kilku wyróżnionych przez siebie generacjach; pierwsza, przypadająca na lata 1230-1260, to czas warowni drewniano-ziemnych wznoszonych w miejscach starych grodów lub w nowych, ważnych strategicznie punktach (Clasen 1927, s. 15). Zdaniem K. H. Clasena w tym czasie powstały także pierwsze murowane zamki o planach nieregularnych, m.in. Starogród, Pokrzywno i Toruń (Clasen 1927, s. 18-22). Z drugą generacją, przypadającą na lata 1260-1290, związane są budowle powstałe na planie regularnym; należy do niej zamek w Bierzgłowie, wzniesiony na planie częściowo załamanego kwadratu (Clasen 1927, s. 29-31). Karl H. Clasen uważał, że z tym okresem związane jest również pojawienie się bergfriedów - charakterystycznych wież; najstarszą była wieża Klimek w Grudziądzu (Clasen 1927, s. 36). Trzeci okres odróżnia się od poprzedniego przede wszystkim stabilizacją budowlaną. Ten tzw. styl dojrzewający przypadał według K. H. Clasena na lata 1290-1320. W tym czasie powstały między innymi zamki w Papowie Biskupim, Golubiu-Dobrzyniu i Lipienku. Ich cechą charakterystyczną jest ciężkość stylu i obronność, czego wyrazem są małe okna. Rzuty tych budowli są w pełni regularne (Clasen 1927, s. 65-72). Czwarta generacja to szczyt rozwoju stylu zamków konwentualnych, przypada on na lata 1320-1350. Był to tzw. okres stylu bogatego i ozdobnego, w którym powstały takie warownie jak Brodnica i Radzyń Chełmiński (Clasen 1927, s. 73-96). Kolejne dwie generacje to czas schematyzacji, stagnacji i przeżywania się stylu; ostatnią, szóstą zamyka rok 1410 (Clasen 1927 s. 97-127). Karl H. Clasen nieco uwagi poświęcił też mniejszym zamkom krzyżackim i warowniom biskupim; te ostatnie określił jako dzieła sztuki drugiej kategorii, które cechuje przejęcie formy i sklasyfikował podobnie jak zamki krzyżackie (Clasen 1927, s. 158-174). Zdaniem K. H. Clasena zamki komturskie były efektem komplikacji ducha rycerskiego i zakonnego; wykształciły się w Prusach, jednak nie w wyniku prostego przejęcia formy, ale na miejscu, na skutek współegzystencji tych obu czynników (Clasen 1927, s. 187-194).

Z kolei B. Schmid w swojej pracy z 1938 roku pt. „Die Burgen des Deutschen Ritterordens in Preußen", omówił rozwój warowni krzyżackich - od drewniano-ziemnych, poprzez nieregularne zamki, do regularnych domów konwentualnych. Jego zdaniem tworzenie się formy murowanej warowni rozpoczęło się na ziemi chełmińskiej, a zakończyło w grupie regularnych zamków nad Zalewem Wiślanym 
w latach 70. XIII wieku (Schmid 1938, s. 5-6). Główne warownie konwentualne o zwartym rozplanowaniu, do których B. Schmid zaliczył między innymi Radzyń Chełmiński i Człuchów, były charakterystyczne dla okresu wielkich mistrzów (po $1309 \mathrm{roku}$ ), natomiast około połowy XIV wieku rozpoczął się proces upraszczania formy, który osiągnął szczyt u schyłku tego stulecia (Schmid 1938, s. 7-8, 17).

W pracy wydanej w 1995 roku Marian Arszyński przedstawił swoiste podsumowanie poglądów na temat genezy i rozwoju tej formy budownictwa warownego w Prusach. Zdaniem tego badacza brakuje dowodów na istnienie ożywionych kontaktów z Ziemią Świętą w okresie kształtowania się w Prusach zamków typu konwentualnego. Nie zgodził się również z koncepcją K. H. Clasena, że rozwój zamku krzyżackiego odbywał się w swoistej izolacji od zewnętrznych wpływów. Uważał, że poszukiwania źródeł inspiracji dla budownictwa zamkowego w Prusach powinno się szukać na szerszych obszarach Europy i wskazał na zamki zbliżone do typu castellum, które z Francji, za pośrednictwem Czech, przenikały na północ (Arszyński 1995). Wcześniej hipotezę o wykształceniu się regularnego modelu zamku konwentualnego z środkowoeuropejskich kaszteli rozwinął i przekonywująco udokumentował Tomaš Durdík (1994, s. 140-236).

W ostatnim okresie na szczególną uwagę zasługuje praca Tomasza Torbusa pt. „Die Konventsburgen in Deutschordensland Preussen” (1998). Jak dotąd, jest to ostatnie monumentalne podsumowanie dziejów architektury zamkowej w Prusach i jej przemian od początku do XV wieku. Dociekania T. Torbusa objęły tylko konwentualne zamki krzyżackie. Badacz w pierwszej części omówił założenia nieregularne (Toruń i Bałga), których forma była efektem wzniesienia ich w miejscach grodów (Torbus 1998, s. 55-70). Osobno zaprezentował zamki o planach dostosowanych do form terenowych, czyli Starogród, Pokrzywno, Bierzgłowo, Grudziądz (Torbus 1998, s. 70-85). Badacz słusznie zwrócił uwagę na to, że pierwsze warownie wznoszono w pośpiechu i miały one przede wszystkim znaczenie obronne. Moment stabilizacji budowlanej nastąpił dopiero po upadku powstań pruskich, powstały wówczas obszerniejsze budynki wewnętrzne, na przykład w Toruniu i Grudziądzu (Torbus 1998, s. 86-87). Tomasz Torbus, podobnie jak K. H. Clasen, uważał, że przejęcie pomieszczeń o charakterze klasztornym miało wpływ na powstawanie regularnych planów (Torbus 1998, s. 85). Najstarszą grupą zamków regularnych, według T. Torbusa, były warownie nad Zalewem Wiślanym (datowane na lata 1270-1300). Wyróżniały się one bogatym wykończeniem, zastosowaniem cegieł glazurowanych i fryzów literowych, planem wydłużonego prostokąta i trójskrzydłowością (Torbus 1998, s. 88-89, 122-124). Zdaniem T. Torbusa cechy i elementy architektoniczne świadczą o tym, że budowniczowie tego zamku przybyli prawdopodobnie z Marchii (Torbus 1998, s. 122-124). Wspomniane zamki poprzedzały warownie konwentualne na planie kwadratu. Pierwsze obiekty zaliczone do tzw. typu konwentualnego (regularnego) pojawiły się na ziemi chełmińskiej w latach 1280-1310; należą do 
nich zamki w Papowie Biskupim, Rogóźnie, Kowalewie Pomorskim i Golubiu oraz Lipienku. Ich typowe cechy to kwadratowa, czteroskrzydłowa forma, brak lub nieukończone wieże główne, brak parchamu i dekoracji z zendrówek oraz surowość i obronność (np. brak dużych okien z wyjątkiem kaplicy); świadczą one o tym, że budowle były symbolem nowej scentralizowanej władzy (Torbus 1998, s. 124-125). Dopiero w następnej fazie (lata 1300-1330) wykształcił się klasyczny kasztel, którego charakterystycznymi elementami były między innymi otwory bramne w wielkich blendach oraz zastosowanie wzorów z zendrówek na elewacjach (np. zamki w Gniewie, Radzyniu Chełmińskim; Torbus 1998, s. 145, 160). Od tej jednorodnej grupy odróżniają się zamki komturskie wznoszone na Pomorzu i Kujawach w latach 1325-1350 (Torbus 1998, s. 176-211). W rozważaniach nad genezą tej formy architektonicznej T. Torbus nie poszukiwał wzorców dla tego typu budowli w odległych rejonach Europy. Według Niego zamki regularne powstawały w różnych miejscach niezależnie. Uważał również, że zamek konwentualny miał wyraźnie widoczny, klasztorny charakter, przejawiający się m.in. w programie dyspozycji wnętrz. Czynnikiem, który wpłynął na przyjęcie tego modelu przez zakon krzyżacki, był scentralizowany i rządzony przez wąską elitę charakter państwa (Torbus 1998, s. 296-297).

Program badawczy dotyczący zamków ziemi chełmińskiej rozpoczęto od badań w Papowie Biskupim (ryc. 1). Miały one przede wszystkim odpowiedzieć na kilka istotnych kwestii odnoszących się do początków warowni, obecności bądź nie osadnictwa poprzedzającego prace budowlane i etapów jej powstawania. Obiekt był analizowany już przez Conrada Steinbrechta, który jest autorem jedynego planu założenia zamkowego oraz przez Johanna Heisego, a także K. H. Clasena i B. Schmida (Steinbrecht 1888, s. 20-24; Heise 1887, s. 161-166; Schmid 1939, s. 114; 1940, s. 73-74). Po drugiej wojnie światowej, pod koniec lat 50. XX wieku, zamek był przedmiotem szczegółowej inwentaryzacji (Arszyński 1958; Sławiński 1959); został też opisany w opracowaniach dotyczących najważniejszych zabytków i zamków w Polsce (Katalog 1973, s. 116-118; Guerquin 1984, s. 249-250; Kajzer, Kołodziejski, Salm 2001, s. 369-370). Warownią papowską zajmowali się również Waldemar Rozynkowski, Tomasz Torbus i Christopfer Herrmann (Rozynkowski 1995; 2002, s. 339-352; Torbus 1998, s. 127-130, 574-581; Herrmann 2007, s. 358-360).

Pierwsze prace wykopaliskowe prowadzono w latach 2005-2008 (Wiewióra 2007, s. 293-305). Badania wznowiono w 2012 roku, skupiając się na weryfikacji rejonu domniemanego parchamu oraz określeniu zasięgu i przebiegu murów przedzamcza (Momot 2012; Wasik 2012). Ich wyniki przyniosły nie tylko sporo zmian w dotychczasowej rekonstrukcji rozplanowania krzyżackiej warowni 


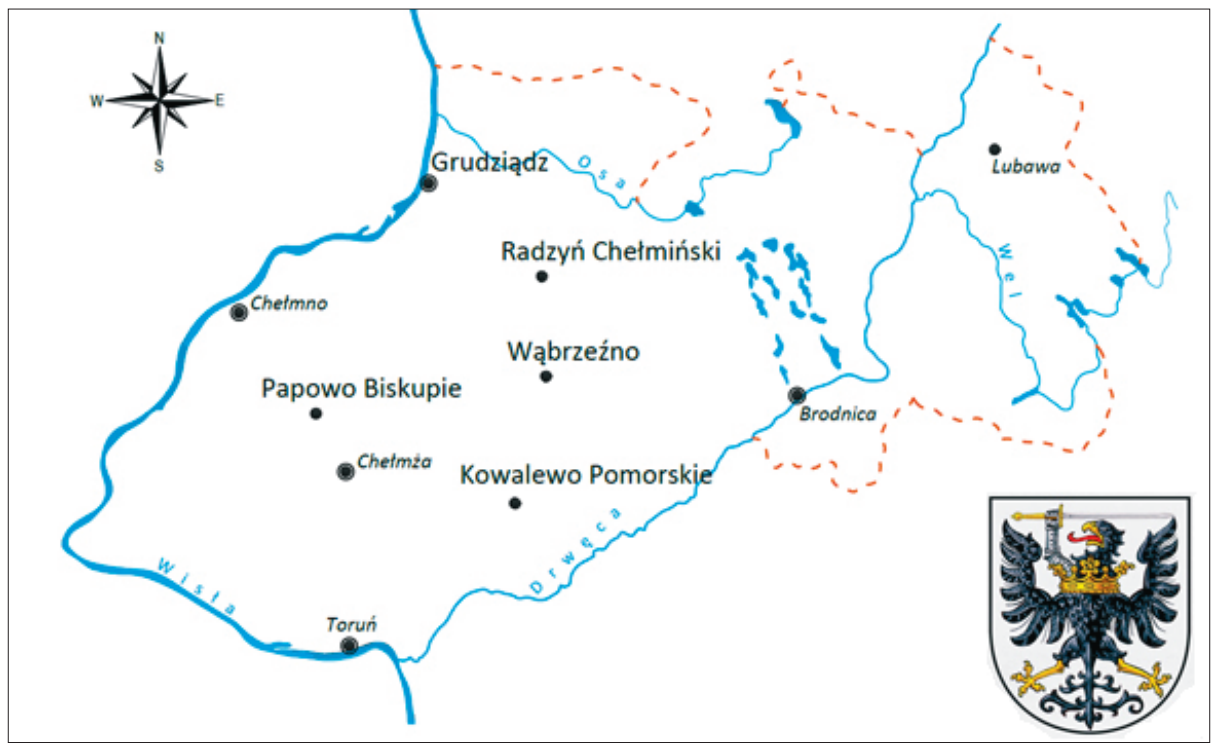

Ryc. 1. Mapa ziemi chełmińskiej z zaznaczoną lokalizacją zamków (oprac. B. Wasik, R. Cisło)

Fig. 1. Map of Chełmno Land with the locations of castles marked (prepared by B. Wasik, R. Cisło)

autorstwa C. Steinbrechta, ale przede wszystkim umożliwiły podjęcie próby rekonstrukcji etapów budowy zamku i charakterystyki technik budowlanych. Najstarsza wzmianka o Papowie Biskupim pochodzi z 1222 roku (PUB 1882, nr 41). Krzyżacy powołali komturię prawdopodobnie pomiędzy 1278 a 1284 rokiem (Jóźwiak 1997, s. 130-132); z tego też czasu pochodzi pierwsza informacja o komturze papowskim - Aleksandrze (PU 1881-1882, nr 377). Prawdopodobnie również wówczas rozpoczęto budowę murowanej warowni (Heise 1887, s. 166; Steinbrecht 1888, s. 20; Clasen 1927, s. 63; Kajzer, Kołodziejski, Salm 2001, s. 370; Herrmann 2007, s. 359). Zdaniem T. Torbusa dom konwentu w Papowie Biskupim należał do najstarszych regularnych, czteroskrzydłowych zamków krzyżackich (Torbus 1998, s. 126-127). Według B. Schmida dojrzały charakter architektury głównych pomieszczeń skrzydła północnego wskazuje, że koniec budowy zamku miał miejsce około 1300 roku (Schmid 1939, s. 114). Takie datowanie zaproponowali również Bohdan Guerquin (1984, s. 249) i Tomasz Torbus (1280-1300; Torbus 1998, s. 127). Pierwszy etap wznoszenia domu konwentu zainicjowały prace ziemne i budowa fundamentów muru obwodowego (Wasik 2013). Na podstawie analizy stratygrafii warstw z wykopów eksplorowanych w ostatnich pięciu sezonach badań oraz analizy technik fundamentowania zrekonstruowano etapy i techniki budowy zamku. Najpierw zbudowano kurtyny na dawnej powierzchni ziemi lub w płytkich wkopach fundamentowych oraz usypano dość grube (około $2 \mathrm{~m}$ ) nawarstwienia 


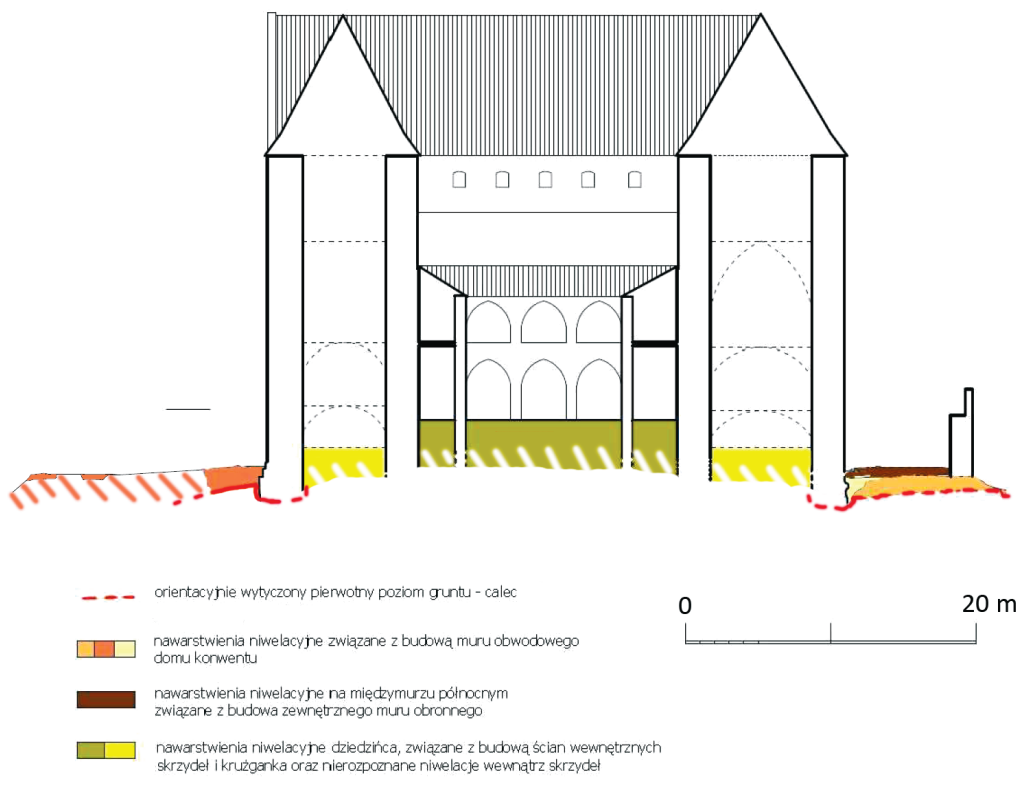

Ryc. 2. Papowo Biskupie, gm. loco. Przekrój poprzeczny obiektu wzdłuż osi północpołudnie z rekonstrukcją kolejnych etapów prac budowlano-niwelacyjnych (wg Wasik 2012)

Fig. 2. Papowo Biskupie, Papowo Biskupie commune. Section of the feature along the north-south axis with the reconstruction of subsequent stages of construction and levelling works (after Wasik 2012)

niwelacyjne (ryc. 2). Analiza budowy ław fundamentowych wykazała, że powstawały one przynajmniej w dwóch fazach, świadczy o tym zastąpienie gliny zaprawą wapienną do wiązania kamieni fundamentu ${ }^{1}$. W drugim etapie wzniesiono mury skrzydła północnego, w którym mieściły się między innymi kaplica i refektarz. W trzecim etapie powstały pozostałe skrzydła zamku; wówczas dopiero przystąpiono do wykończenia krużganka. Badania z 2012 roku wykazały również, że nie było parchamu otaczającego dom konwentu, a od północy istniał jedynie zewnętrzny mur płytko fundowany i międzymurze (ryc. 3) $)^{2}$. Analiza stratygrafii w wykopach nie potwierdziła obecności fosy oddzielającej zamek wysoki od przedzamcza, które osłaniał tylko płytko fundowany mur obronny (ryc. 4).

\footnotetext{
${ }^{1}$ Ten sposób konstrukcji zaobserwowano zarówno w przypadku muru obwodowego, jak i w wewnętrznych ścianach skrzydeł (Wasik 2012; szczegółowo na temat technik fundamentowania - por. Wiewióra 2005; 2006; 2007; 2008.

${ }^{2}$ Typowy parcham jest przestrzenią międzymurza o formie tarasu wyniesionego ponad otaczający teren.
} 


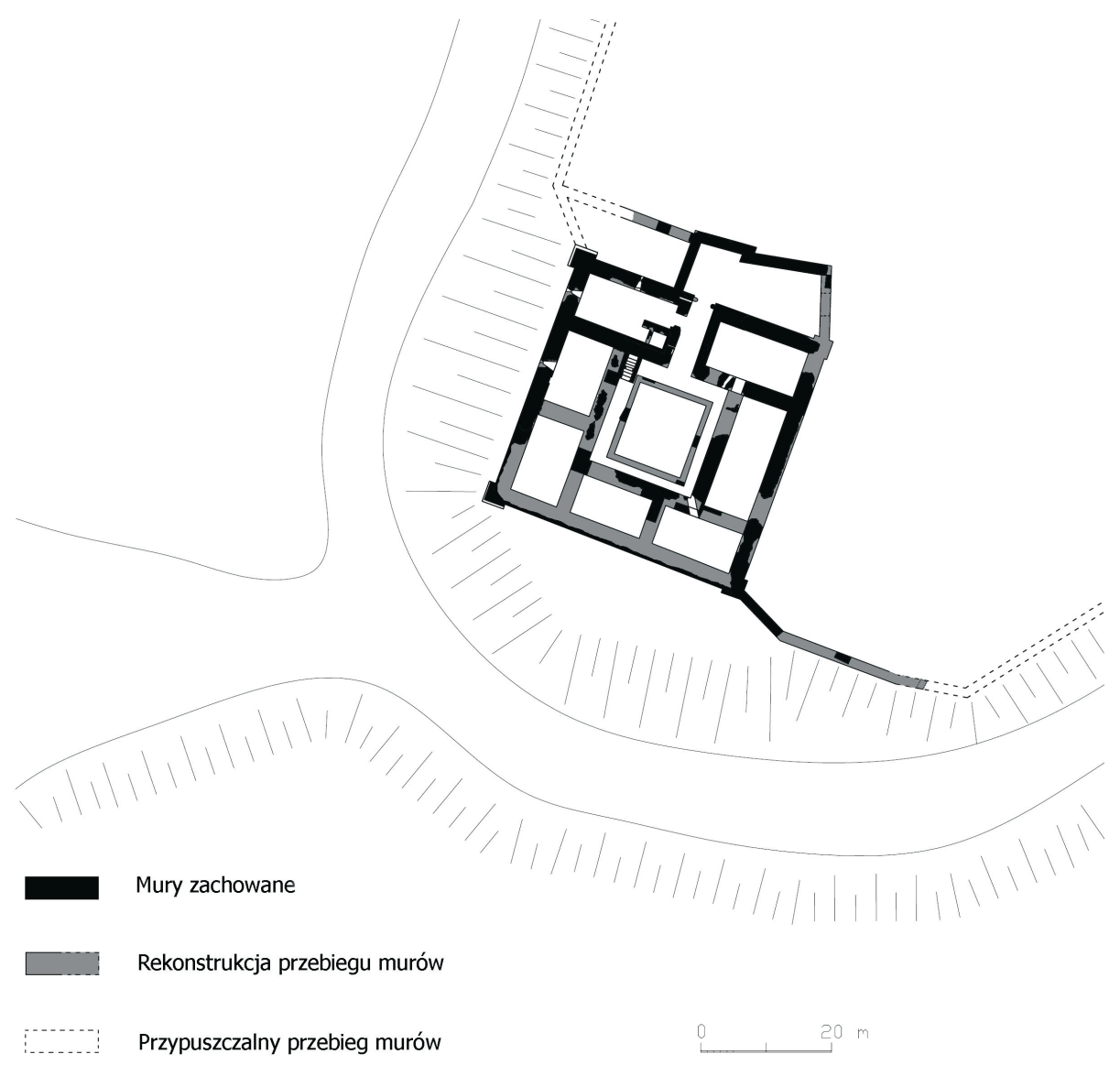

Ryc. 3. Papowo Biskupie, gm. loco. Rekonstrukcja zamku górnego po badaniach w 2012 roku (oprac. B. Wasik)

Fig. 3. Papowo Biskupie, Papowo Biskupie commune. Reconstruction of the upper castle after excavations in 2012 (prepared by B. Wasik)

Natomiast ciekawych informacji na temat warsztatu budowlanego, a przy okazji również środowiska przyrodniczego w jakim przyszło działać budowniczym, przyniosły odkrycia z 2013 roku. Już rok wcześniej, podczas szczegółowych oględzin murów zamkowych odkryto, że otwory maculcowe kryją wewnątrz dobrze zachowane pozostałości drewnianych, zapewne oryginalnych belek, stanowiących część rusztowań (ryc. 5). Pozyskano wówczas jedną próbkę drewna, która po bliższych analizach okazała się wiązem. Jest to gatunek drewna odporny szczególnie na gnicie. Wiąz najczęściej rośnie na grądach i łęgach, czyli w środowisku leśnym występującym nad rzekami i potokami. Potwierdzeniem tych obserwacji były kolejne próbki uzyskane w 2013 roku z trzech otworów, 


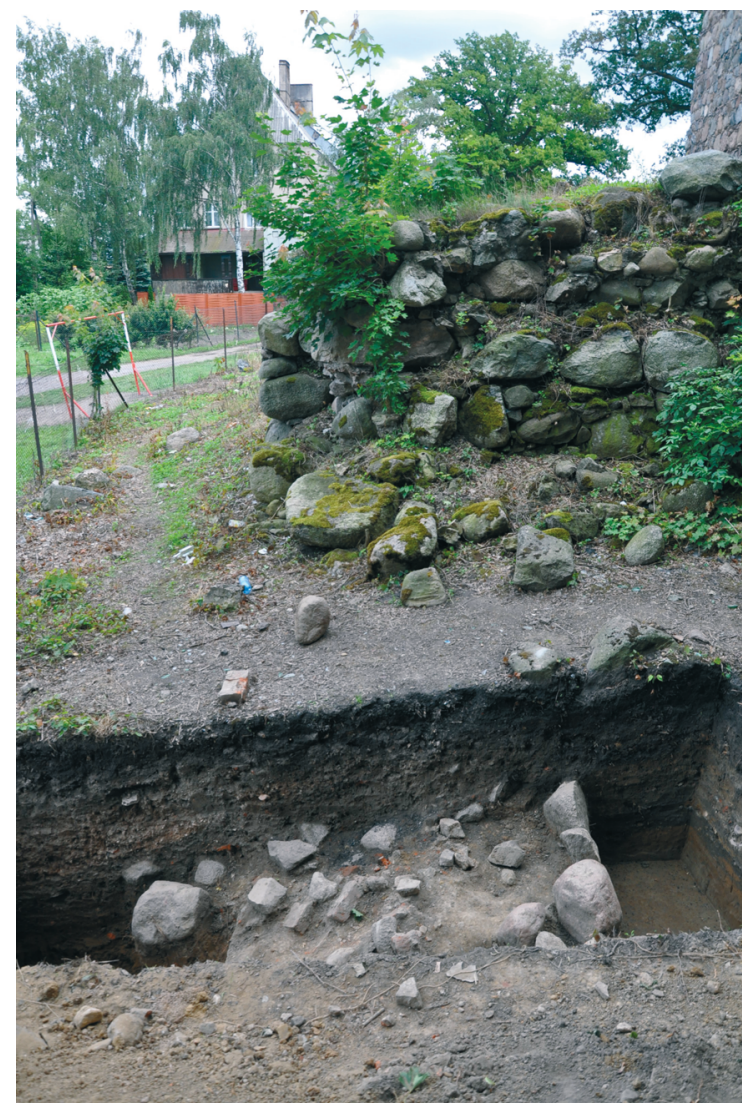

Ryc. 4. Papowo Biskupie, gm. loco. Widok od zachodu fragmentu zewnętrznego muru międzymurza (fot. B. Wasik)

Fig. 4. Papowo Biskupie, Papowo Biskupie commune. View from the west of the outer interwalls wall portion (photo B. Wasik)

należące do wiązów i jesionu. Niestety, żadna z nich nie nadawała się do analiz dendrochronologicznych, zatem nie było możliwe dokładne ustalenie, kiedy przystąpiono do budowy murowanego, kamiennego zamku w Papowie Biskupim, a przynajmniej określenie w przybliżeniu, czasu ukończenia prac nad I/III etapem wznoszenia zamku.

Interesujące informacje na temat warsztatu budowlanego uzyskano również podczas badań zamku górnego w Radzyniu Chełmińskim (ryc. 6). Pierwsze prace zabezpieczające i badawcze obiektu realizowano w latach 1886-1890. Zainteresowanie warownią pod kątem analiz historycznych i architektonicznych rozpoczęło się już w XIX i kontynuowane były w początkach XX wieku (Heise 1894; Clasen 1927; Schmid 1939). Po drugiej wojnie światowej przeprowadzono 


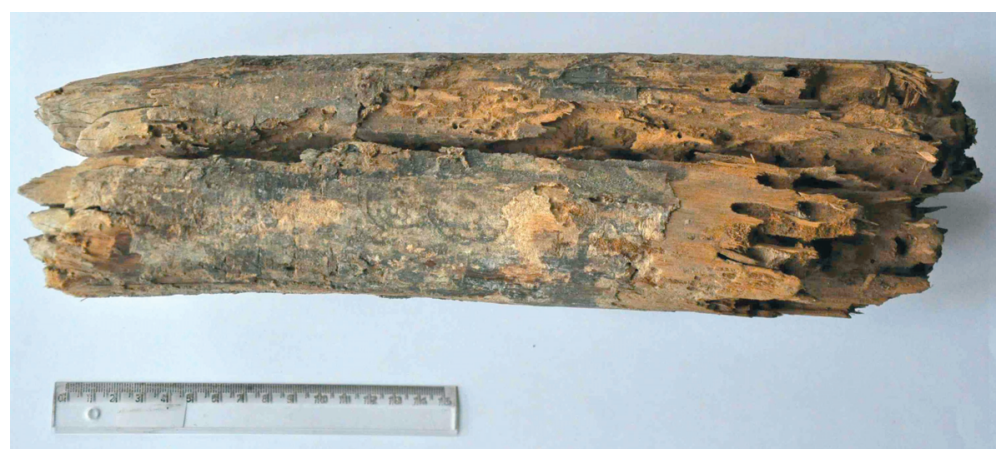

Ryc. 5. Papowo Biskupie, gm. loco. Fragment drewna wydobytego z otworu maculcowego (fot. B. Wasik)

Fig. 5. Papowo Biskupie, Papowo Biskupie commune. Fragment of wood extracted from a putlog hole (photo B. Wasik)

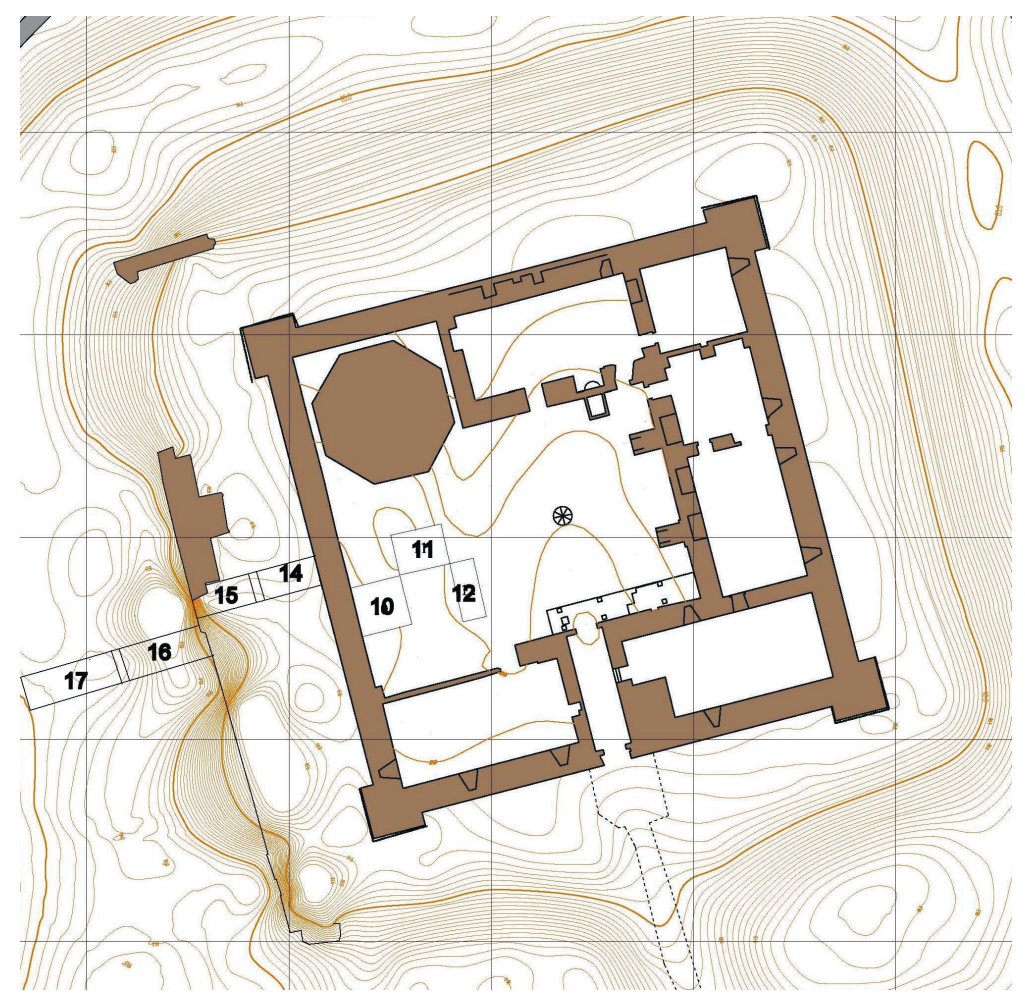

Ryc. 6. Radzyń Chełmiński, gm. loco. Rzut zamku górnego z lokalizacją wykopów badanych w latach 2008-2009 (rys. R. Łopaciuk, M. Wiewióra)

Fig. 6. Radzyń Chełmiński, Radzyń Chełmiński commune. Plan of the upper castle with the location of trenches excavated in 2008-2009 (drawing R. Łopaciuk and M. Wiewióra) 
kwerendę historyczną, inwentaryzację architektoniczną, a w latach 1961-1968 odgruzowano część piwnic (Arszyński 1961). W 1984 roku zrealizowano prace zabezpieczające fragmenty murów przedzamcza południowego (Sławiński 1957; 1962; 1964; 1965; 1967; Arszyński 1961; Sławiński, Czaplińska, Majewski 1984). Pierwsze planowe prace archeologiczne podjęła w 1957 roku Gabriela Mikołajczyk, która odgruzowała wieżę położoną w północno-zachodnim narożniku zamku (Mikołajczyk 1960). W latach 1963-1964, w związku z podjętymi pracami konserwacyjnymi zamku, rozpoczęto badania archeologiczne pod kierunkiem Januariusza Janikowskiego i Jana Grześkowiaka (Janikowski 1963a; 1963b) ${ }^{3}$.

Zamek główny wzniesiono na planie czworoboku o wymiarach 49,4 × 49,6 m (Torbus 1998, s. 597). Fundamenty oraz częściowo mury piwnic zbudowano $\mathrm{z}$ kamienia narzutowego $\mathrm{w}$ niewielkim stopniu uzupełnionego cegłami. Pozostałą część murów, powyżej poziomu piwnic, wzniesiono z cegieł w wątku wedyjskim i polskim (Arszyński 1961, s. 46). Budynek konwentu w narożnikach flankowały cztery kwadratowe wieżyczki wysunięte przed lico muru. W północno-zachodnim narożniku dziedzińca znajdowała się ośmioboczna wieża. W południowym skrzydle zamku głównego położona była jedyna brama prowadząca na dziedziniec (Arszyński 1961, s. 45; 1995, s. 186; Torbus 1998, s. 598). Zamek główny otaczało ze wszystkich stron szerokie na około $12 \mathrm{~m}$ międzymurze. Resztki muru z fragmentami danskeru zachowały się od strony zachodniej; pierwotnie baszta ustępowa była połączona ze skrzydłem zachodnim zamku (Arszyński 1961, s. 45). To właśnie obserwacje z tej części obiektu dostarczyły nowych danych. Podobnie jak w Papowie Biskupim, udało się zrekonstruować kilka etapów prac budowlanych. Obserwacje stratygrafii warstw odkrytych w trzech wykopach eksplorowanych po zachodniej stronie zamku, w przestrzeni międzymurza i na terenie dawnej fosy zamkowej wykazały, że przed przystąpieniem do budowy zewnętrznych kurtyn zamku prace budowlane zainicjowały bardzo intensywne i czasochłonne niwelacje terenu, na którym zaplanowano wznoszenie twierdzy (ryc. 7). Z analiz profilu wykopów 14-15 wynika, że wstępnie wykonano płytki wkop na ławę fundamentu, który dalej wznoszono z wolnej ręki. Dopiero w kolejnej fazie nadsypano ziemię po zachodniej stronie muru. Przed przystąpieniem do budowy murów cały teren znacznie podwyższono, usypując z żółtej gliniastej ziemi charakterystyczne plateau, wyznaczając jednocześnie miejsca, w których przewidziano fosę zamkową.

Nowe dane i szereg odpowiedzi na zasadnicze pytania stawiane w ramach realizowanego projektu przyniosły badania zamku w Grudziądzu, prowadzone w 2008 i 2009 roku (Zamek w Grudziądzu 2012). Realizowano je na zlecenie Urzędu Miasta Grudziądza, który podjął decyzję o rewitalizacji Góry Zamkowej i pozostałości murów zamku. Najważniejszym zadaniem było ustalenie etapów

\footnotetext{
${ }^{3}$ Nowy etap badań zamku rozpoczął się w 2007 roku; prace archeologiczno-architektoniczne były wówczas prowadzone przez Instytut Antropologii i Archeologii Akademii Humanistycznej im. Aleksandra Gieysztora, pod kierunkiem mgr. Dariusza Gazdy. Realizowano je na terenie przedzamcza południowego, w jego południowo-wschodniej i zachodniej części.
} 


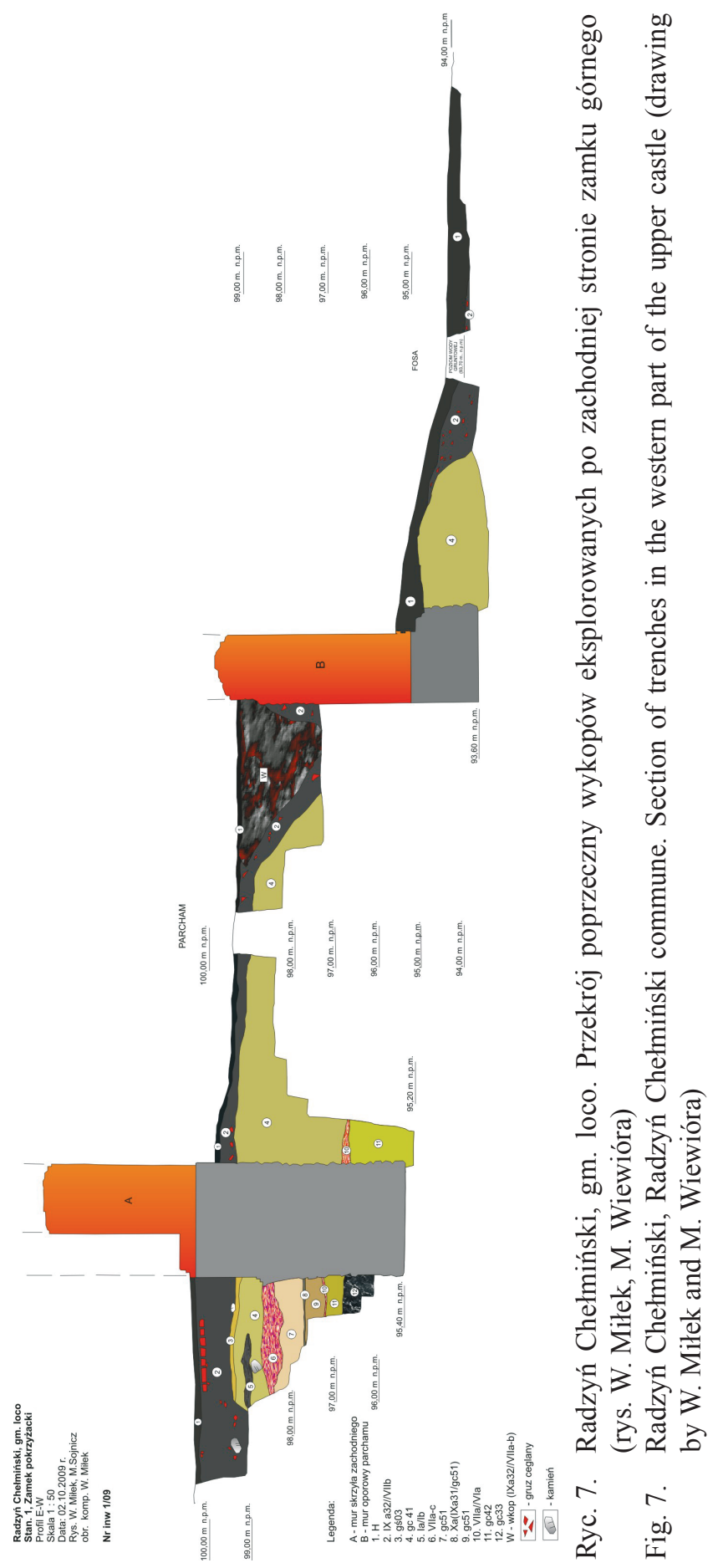


budowy warowni, a szczególnie jej układu przestrzennego w kolejnych fazach rozwoju. Podobnie jak wiele innych zamków w tym czasie, także grudziądzki, decyzją władz pruskich został niemal całkowicie rozebrany w początkach XIX stulecia. Również późniejsze prace budowlane prowadzone na terenie Góry Zamkowej doprowadziły do niemal całkowitego zniszczenia znacznej części obiektu. Przez blisko 60 lat, od zakończenia pierwszych prac archeologicznych w latach 1940-1941, dyskusja na temat jego historii była ograniczona (np. Atlas historyczny 1997; Torbus 1998).

Zamek w Grudziądzu powstał na wyniesieniu, około $60 \mathrm{~m}$ ponad poziomem lustra Wisły, na wschodnim brzegu rzeki. Podczas badań prowadzonych w 2008 i 2009 roku dobrze zachowany i nienaruszony układ stratygraficzny stwierdzono jedynie w kilku punktach badanego stanowiska. Analizy geomorfologiczne i geologiczne wykazały, że obszar położony w południowej części tzw. Kępy Fortecznej, z jego kulminacją w postaci Góry Zamkowej jest najbardziej przetworzonym antropogenicznie fragmentem na całej długości skarpy (Kordowski, Tyszkowski, Bienias 2012). Badania archeologiczne prowadzone w 2009 roku wykazały, że pierwsze prace budowlane w XIII i XIV stuleciu doprowadziły do znacznych przekształceń pierwotnej powierzchni, niszcząc między innymi pozostałości osadnictwa wczesnośredniowiecznego ${ }^{4}$.

Jednym z najważniejszych wyników badań zamku w Grudziądzu była ostateczna weryfikacja hipotezy o wczesnośredniowiecznej osadzie grodowej na terenie Góry Zamkowej (Froelich 1884-1885; Szmid 1929, s. 64; Szymański 1960, s. 73-74; Torbus 1998, s. 80-81; Kajzer, Kołodziejski, Salm 2001, s. 199-200). Najbardziej przekonywujące dowody na możliwość istnienia grodu w Grudziądzu dostarcza tzw. dokument z Lonyz z 1223 roku (Bieniak 1970, s. 12-24 - tam starsza literatura; Powierski 1973; Jasiński 1992, s. 151-163; Chudziak 1996, s. 25-34). Wśród 11 dawnych grodów - quondam castra - wymieniono tam Grudziądz (Chudziak 1996, s. 27; Poliński 2007a, s. 158-159). Zgodnie z tymi informacjami uważa się, że gród funkcjonował już około 1222 roku (castrum), a 12 lat później został przejęty przez Krzyżaków (Heise 1894, s. 427; Torbus 1998, s. 427; Poliński 2007a, s. 159-160). Fragmenty naczyń ceramicznych datowanych na okres wczesnośredniowieczny odkrywano wielokrotnie podczas badań prowadzonych w tym rejonie Grudziądza (Boguwolski, Kola 1972, s. 54-58; Jacobi 1996). Jednak dopiero w 2009 roku udało się zarejestrować ślady osadnictwa przedkrzyżackiego, datowanego od neolitu do wczesnego średniowiecza włącznie (Bokiniec 2012; Chudziak, Kurzyńska 2012; Gackowski 2012). Odkryto między innymi pozostałości budynków mieszkalnych z paleniskami (ryc. 8), nie znaleziono natomiast

${ }^{4}$ Poza tym na obszarze Góry Zamkowej kilkakrotnie rejestrowane były wielkie ruchy osuwiskowe. Największy, odnotowany w źródłach, miał miejsce w 1388 roku, kiedy po długotrwałych opadach deszczu, przy wysokim stanie Wisły, oberwał się zachodni fragment Góry Zamkowej. Zniszczeniu uległ wówczas bliżej nieokreślony fragment zachodniej części zamku z pomieszczeniami mieszkalnymi komtura. 


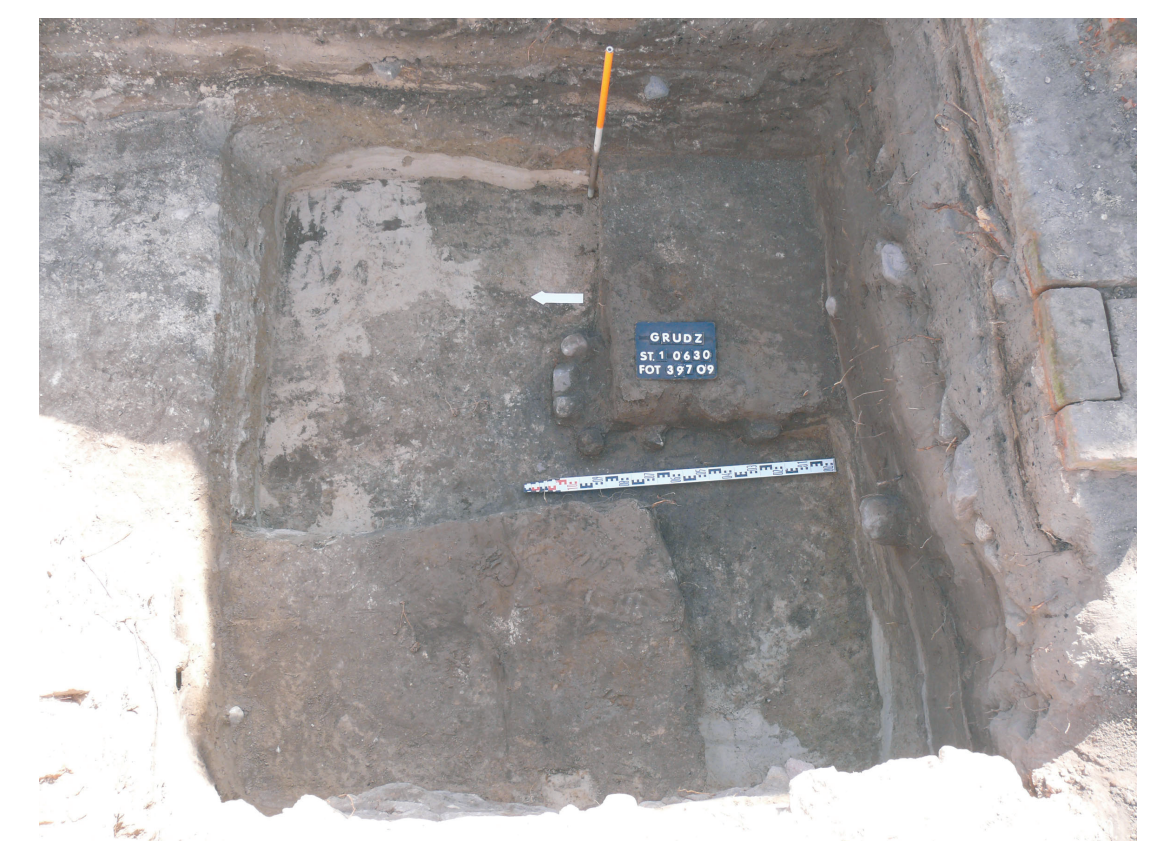

Ryc. 8. Grudziądz. Rzut poziomy reliktów wczesnośredniowiecznej chaty (fot. M. Wiewióra)

Fig. 8. Grudziądz. Plan of the remains of the early medieval hut (photo M. Wiewióra)

żadnych reliktów urządzeń obronnych (fortyfikacji), zatem problem istnienia osady o charakterze obronnym pozostaje nierozstrzygnięty. Wpływ na to ma z pewnością specyficzne ukształtowanie terenu oraz prace budowlane prowadzone od 2. połowy XIII wieku. Należy również pamiętać, że charakter wzniesionych w tym miejscu drewniano-ziemnych fortyfikacji ograniczał się - być może - tylko do wału odgradzającego południowy, przewężony fragment najniżej położonej części cypla, na którym powstał później zamek (Bieniak 1970, s. 5-69; Boguwolski, Kola 1972, s. 54-64; Chudziak 1996, s. 25-34).

Wszyscy badacze zajmujący się początkami zamku grudziądzkiego moment rozpoczęcia budowy jego murowanej fazy wiązali z datą powstania komturstwa grudziądzkiego (Torbus 1998, s. 80-82). Najstarszą wzmianką na ten temat jest informacja pochodząca z 1250 roku o urzędowaniu na zamku pierwszego komtura - Bertolda (m.in. Schmid 1929, s. 64; Szymański 1960, s. 75; Torbus 1998, s. 81; 427; Kajzer, Kołodziejski, Salm 2001, s. 199-201). W opisie wizytacji zamku z 1667 roku znalazła się wzmianka o kaplicy zamkowej wzniesionej około 1290 roku. Z kolei w lustracji z 1739 roku wspomina się o tym, że budowa kaplicy zamkowej zakończyła się w 1299 roku (Jacobi 1996, s. 70; Jóźwiak, Trupinda 2012, s. 3). 
Najstarsza, murowana zabudowa być może istniała już około roku 1267, kiedy w Grudziądzu przebywał mistrz krajowy (np. Schmid 1929, s. 64; Szymański 1960, s. 77). Według źródeł historycznych w 1277 roku miasto było oblegane przez Prusów (Dusburg 2004, s. 150-151). Przypuszczano nawet, że w tym czasie mury miejskie musiały być zniszczone, skoro w 1286 roku Krzyżacy na wieść o zbliżających się wojskach tatarskich, zmusili mieszkańców do opuszczenia miasta. Być może zatem zniszczenia objęły również powstający właśnie zamek W ten sposób można by wytłumaczyć dlaczego obiekt powstawał 50 lat (por. niżej). W 1288 roku na zamku gościł mistrz krajowy Meinhard z Querfurtu w towarzystwie komturów Chełmna, Rogóźna, Torunia i Radzynia (Szymański 1960, s. 77). Odwiedził on zamek ponownie, w 1291 roku, podczas wizytacji robót polegających na sypaniu wzdłuż Wisły wału przeciwpowodziowego. Z pewnością warownia była już w pełni ukończoną budowlą w latach 30. XIV wieku, skoro w 1330 roku stała się kwaterą główną dowództwa wojsk krzyżackich podczas wojny z królestwem polskim (Szymański 1960, s. 78).

Zweryfikowane przez historyków daty pojawienia się urzędów komturskich wskazują jednak, że zamki w Pokrzywnie, Bierzgłowie czy Malborku powstały dopiero w latach 1270-1283 (Jóźwiak, Trupinda 2012). W związku z tym przyjmowana dotąd chronologia budowy zamku grudziądzkiego musi być odpowiednio skorygowana. Początki komturstwa grudziądzkiego można datować na okres między 1263 a 1269 rokiem (Jóźwiak, Trupinda 2012). Ukończenie budowy najbardziej reprezentacyjnego wnętrza zamku - kaplicy - lub też jego całej bryły nastąpiło dopiero pod koniec XIII stulecia. Zapewne dopiero po $1300 \mathrm{roku}$ wzniesiono skrzydło zachodnie, przebudowane (lub odbudowane?) po $1388 \mathrm{roku}$, a wzdłuż północnego i wschodniego muru obwodowego powstała w ciągu XIV i XV, a nawet w XVI wieku lekka zabudowa o trudnej do sprecyzowania liczbie poziomów i strukturze (Schmid 1929, s. 66-67; Jakobi 1996, s. 28-29, 35-36, 39; Torbus 1998, s. 81, 433-434).

Wyniki badań archeologicznych prowadzonych w latach 2008 i 2009 w wielu kwestiach zgodne są z wcześniejszymi ustaleniami dotyczącymi rekonstrukcji układu przestrzennego zamku (Wiewióra 2012a). Zestawienie planigrafii odkrytych reliktów murów bądź negatywów z planami obiektu z XVII i XVIII wieku, czy rekonstrukcją Hansa Jacobiego z lat 40. XX wieku, potwierdziło w ogólnych zarysach, że było to nieregularne, trapezowate założenie, w którym głównym elementem i dominantą było masywne skrzydło południowe $\mathrm{z}$ bramą wjazdową prowadzącą na dziedziniec. Z ustaleń tych wynika również, że powstało ono w dwóch fazach budowlanych (Zimnowoda-Krajewska 2012). Na podstawie rozwarstwienia architektonicznego murów oraz analizy przekazów historycznych i ikonograficznych można obecnie wyznaczyć sześć głównych okresów w historii zamku grudziądzkiego. Nie można dziś jednoznacznie stwierdzić czy w miejscu, w którym rozpoczynano budowę murowanego zamku istniała wcześniej osada 
obronna (gród wczesnośredniowieczny). Z całą pewnością natomiast w fazie I, w miejscu powstania czworoboku murów obwodowych wraz z wieżą istniała osada. Nie udało się ustalić z jakiego okresu pochodzi Klimek - wieża pełniąca zapewne funkcję tzw. twierdzy ostatecznej obrony. W szczegółowych opracowaniach poświęconych zamkowi grudziądzkiemu wskazywano na charakterystyczny pas cegieł zendrówek - glazurowanych, typowych dla budownictwa krzyżackiego ostatniej ćwierci XIII wieku (Torbus 1998, s. 84). Pasy glazurowanej cegły, widoczne na rysunkach wykonanych przez C. Steinbrechta w dolnej części wieży (do wysokości wejścia) układały się tylko od strony widocznej z dziedzińca, nie ma ich natomiast od strony zasłoniętej przez mury kurtynowe. Zastosowanie ozdobnych pasów na pełnym obwodzie w górnej części wieży, dobrze widocznej ze wszystkich stron, i jej brak w miejscu, które przysłaniała kurtyna zachodnia, raczej jednoznacznie świadczy o tym, że wieża powstała dopiero po wzniesieniu murów obwodowych zamku lub też w momencie ich podwyższenia (Steinbrecht 1888, s. 47. Interpretacja wg B. Wasika). Kamienne ławy fundamentowe murów obwodowych powstały etapami: najpierw od południa i wschodu, a następnie od zachodu i północy. Dostęp do zamkowego dziedzińca zapewniała brama umieszczona w tym samym miejscu, co późniejszy przejazd bramny (Zimnowoda-Krajewska 2012). W drugiej fazie budowy powstała zachodnia część skrzydła południowego. Drugi etap budowlany można wiązać z zakończeniem budowy kaplicy zamkowej w 1299 roku. Wydaje się, że dopiero po zakończeniu budowy skrzydła południowego, w III etapie, przystąpiono do wznoszenia skrzydła zachodniego. Wraz z zakończeniem budowy tego skrzydła logiczne było dostawienie od strony Wisły gdaniska z systemem komunikacji i murem parchamu. Prawdopodobnie w tej fazie powstała murowana zabudowa skrzydła zachodniego. Początek tego etapu prac datujemy na okres po 1299 roku, czyli po zakończeniu prac budowlanych w skrzydle południowym (ryc. 9).

Kolejny obiekt będący przedmiotem badań archeologiczno-architektonicznych, zamek w Wąbrzeźnie, nie należy do klasycznych zamków krzyżackich, ale rezydencji biskupich. Nie został również zbudowany w XIII wieku, ale zapewne w pierwszej dekadzie następnego stulecia. Jednak obserwacje dokonane podczas prac archeologiczno-architektonicznych dostarczyły szeregu interesujących danych dotyczących na przykład warsztatu budowlanego charakterystycznego dla końca XIII stulecia ${ }^{5}$.

Ceglane założenie zamku w Wąbrzeźnie, które było badane w latach 2010-2011, składało się z trójskrzydłowego zamku głównego na planie kwadratu o boku $60 \mathrm{~m}$, z wewnętrznym dziedzińcem (ryc. 10-11). Z trzech stron otaczały go jednotraktowe, dwukondygnacyjne skrzydła mieszkalne. Od wschodu założenie zamykał mur obwodowy, pośrodku którego wznosiła się oktagonalna wieża, flankująca wjazd do zamku (Baciński 2004, s. 43-52). Podobnie jak w przypadku Kowalewa

${ }^{5}$ W 2014 r. ukaże się publikacja pt: „,Zamek biskupów w Wąbrzeźnie. Studia i materiaty” dzięki dofinansowaniu Ministra Kultury i Dziedzictwa Narodowego, umowa 3789/14/FPK/NID. 


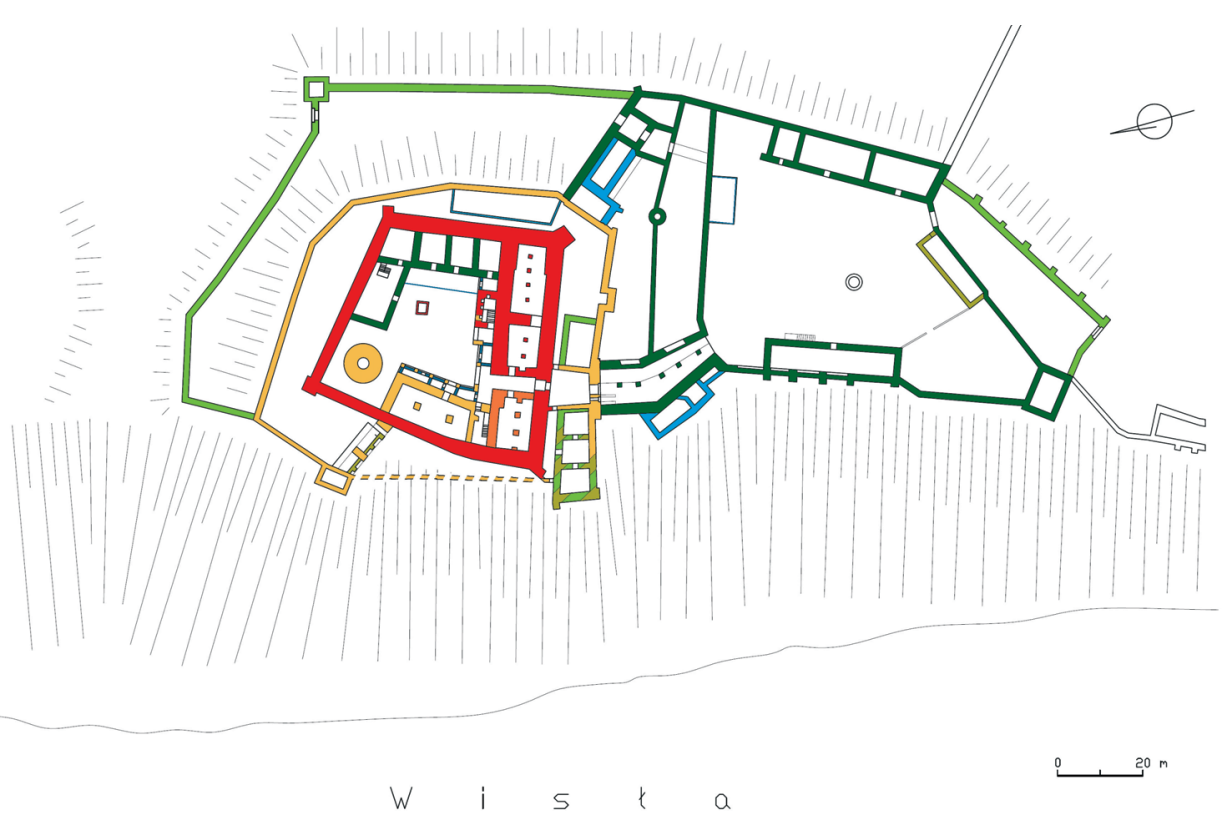

Ryc. 9. Grudziądz. Rekonstrukcja etapów budowy zamku i przedzamcza (oprac. B. Wasik) Fig. 9. Grudziądz. Reconstruction of the construction stages of the castle and forebuilding (prepared by B. Wasik)

Pomorskiego nie dysponujemy obecnie żadnymi sprawdzonymi informacjami dotyczącymi topografii zamku, układu przestrzennego i lokalizacji pomieszczeń. Nie zachowały się również źródła ikonograficzne. Reprezentacyjną częścią zamku górnego było zapewne podpiwniczone skrzydło południowe, w którym mieściła się kaplica pod wezwaniem św. Marka oraz refektarz.

Badania zamku w Wąbrzeźnie dostarczyły zwłaszcza cennych źródeł do poznania warsztatu budowlanego, który na podstawie wyników szczegółowych analiz można wpisać w schematy obowiązujące w końcówce XIII stulecia. Na szczególną uwagę zasługują fragmenty maswerku, fryzu oraz dobrze zachowany element fosy zamkowej (ryc. 12). Fragment ceglanego fryzu złożonego $\mathrm{z}$ czwórliści o półkolistych płatkach wpisanych $\mathrm{w}$ rozety przypomina elementy charakterystyczne na ziemi chełmińskiej, znane z wielu budowli, na przykład w Radzyniu Chełmińskim (ryc. 13) - z elewacji południowej, a także z Chełmży, ze ściany międzywieżowej katedry (Sławiński, Cabała 1966, s. 4-5; Mroczko 1980, s. 249) ${ }^{6}$. Katedrę w Chełmży wzniesiono w latach 1293-1311, wzorując się

${ }^{6}$ Zastosowanie tych i innych kształtek dowodzi, że podczas budowy katedry w Chełmży korzystano z produkcji ceglarskiej Zakonu uzupełniając te cegły, które wytwarzał pracujący przy budowie warsztat. Pewne związki kształtek zastosowanych w elewacji północnej katedry widać również z fryzem czwórlistnym zastosowanym w spichlerzu na Zamku Średnim w Pokrzywnie i w Krzywej Wieży w Toruniu. 


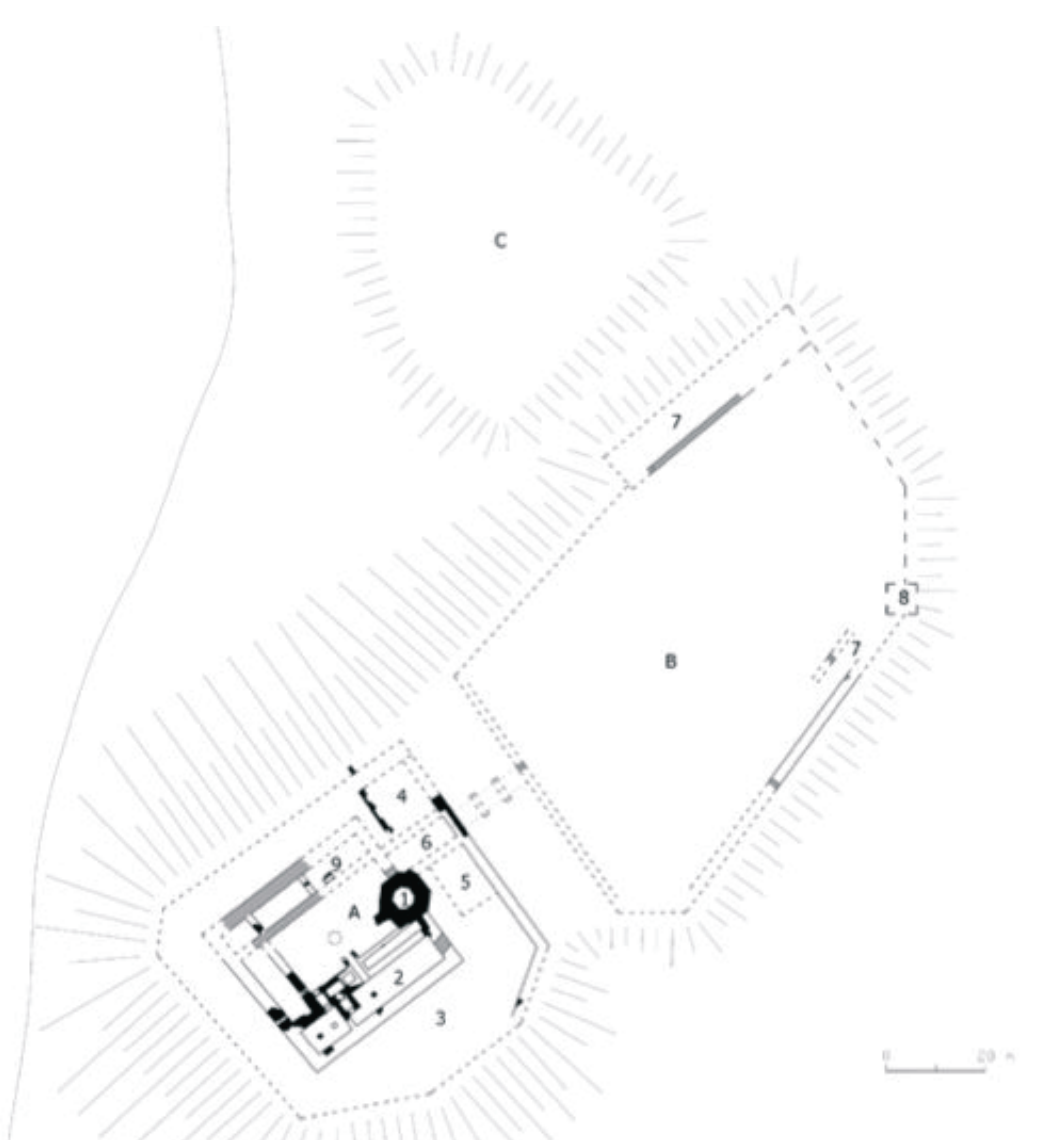

Ryc. 10. Wąbrzeźno, gm. loco. Rekonstrukcja zamku i podzamcza (oprac. B. Wasik)

Fig. 10. Wąbrzeźno, Wąbrzeźno commune. Reconstruction of the castle and the bailey (prepared by B. Wasik)

na tzw. szkole marburskiej. W końcu wieku XIII lub na początku XIV, w okresie wzmożonej ekspansji Zakonu na Pomorzu Wschodnim, krzyżaccy biskupi Henryk lub Herman, podejmując budowę korpusu nawowego katedry, nawiązującej do kościoła św. Elżbiety w Marburgu, usiłowali dokonać nowelizacji tradycyjnego programu budowlanego i nadać jej wyraźne krzyżackie piętno. Bliskie analogie dla układu planistycznego tej części katedry można znaleźć w kościele NMP w Chełmnie. Po śmierci biskupa Hermana w 1311 roku diecezję chełmińską objął biskup Mikołaj (1319-1323). Za jego rządów prawdopodobnie wzniesiono międzywieżową ścianę fasady (Mroczko 1980, s. 124-126). Okulus lub rozeta, będąca głównym elementem dekoracyjnym fasady, jest charakterystyczna dla architektury północnowłoskiej XII-XIV wieku oraz wczesnych budowli cysterskich (np. Chorin - 1273-1334). Identyczne kształtki zastosowano również jako fryz 


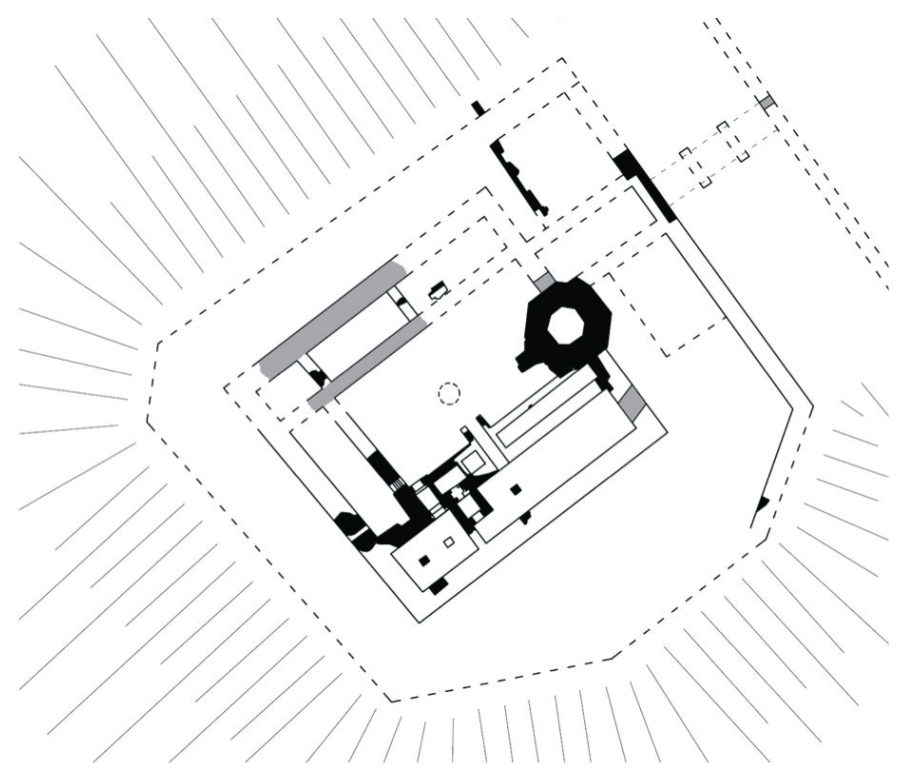

Ryc. 11. Wąbrzeźno, gm. loco. Rzut poziomy reliktów i rekonstrukcja planu zamku górnego (oprac. B. Wasik)

Fig. 11. Wąbrzeźno, Wąbrzeźno commune. Plan of the remains and reconstruction of the layout of the upper castle (prepared by B. Wasik)

koronujący w korpusie kościoła NMP w Chełmnie ukończonym około 1320 roku. Dekoracja środkowej części fasady katedry w Chełmży powstała zapewne w zbliżonym czasie (Heise 1887, s. 46; Mroczko 1980, s. 47-48, 126, il. 29-31, 57-58). Jej budowa przypada prawdopodobnie na krótki okres rządów Mikołaja, który w Chełmży przebywał dwa lata (1320-1322). Cegły użyte do budowy fryzów na zamku wąbrzeskim są znacznie mniejsze niż zastosowane w budowlach Chełmży i Chełmna. Fryz wykonany z tak niewielkich elementów byłby słabo widoczny na szczycie budynku. Dodatkowo ślady pokrycia wapienną zaprawą ornamentu ceglanego fryzu wskazuje raczej na użycie takiego wystroju wewnątrz budynku lub w zadaszonym krużganku (Sławiński, Cabała 1966, s. 4-5; Torbus 2004, s. 219-238; Majewski 2010) ${ }^{7}$.

${ }^{7}$ Podobny, jednak wzniesiony w zupełnie innej technice fryz koniczynkowy z profilówkami, znajduje się na północnej i zachodniej stronie średniowiecznego spichlerzu w Pokrzywnie. Jego część składową stanowi powtarzający się motyw czterolistnej koniczyny, złożonej z czterech profilówek, $\mathrm{z}$ obustronnym wykrojem w długości cegieł. Fryz ten jest wgłębiony w podłużny fryz kordonowy, którego tło było otynkowane. Obecnie fryz koniczynkowy zachował się tylko w elewacji północnej oraz fragmentarycznie przy ryzalicie wieżowym w narożniku północno-zachodnim. Budowę zamku datuje się na koniec XIII-lub początek XIV stulecia. Natomiast elementy architektury, w tym fryz koniczynkowy, bramy przedzamcza i strzelnic oraz wjazdów do stodoły pochodzą z połowy XIV wieku (Torbus 2004, s. 219-238). Płyty ceramiczne z wyciskanym w drewnianej formie wzorem pojawiły się w zamkach krzyżackich od około 1270 roku. Fryzy z motywami roślinnymi znane są z zamków w Malborku i Lochstedt. 
Ryc. 12. Wąbrzeźno, gm. loco. Fragmenty fryzu odkryte podczas badań zamku (fot. M. Majewski)

Fig. 12. Wąbrzeźno, Wąbrzeźno commune. Fragments of a frieze discovered during excavations in the castle (photo M. Majewski)
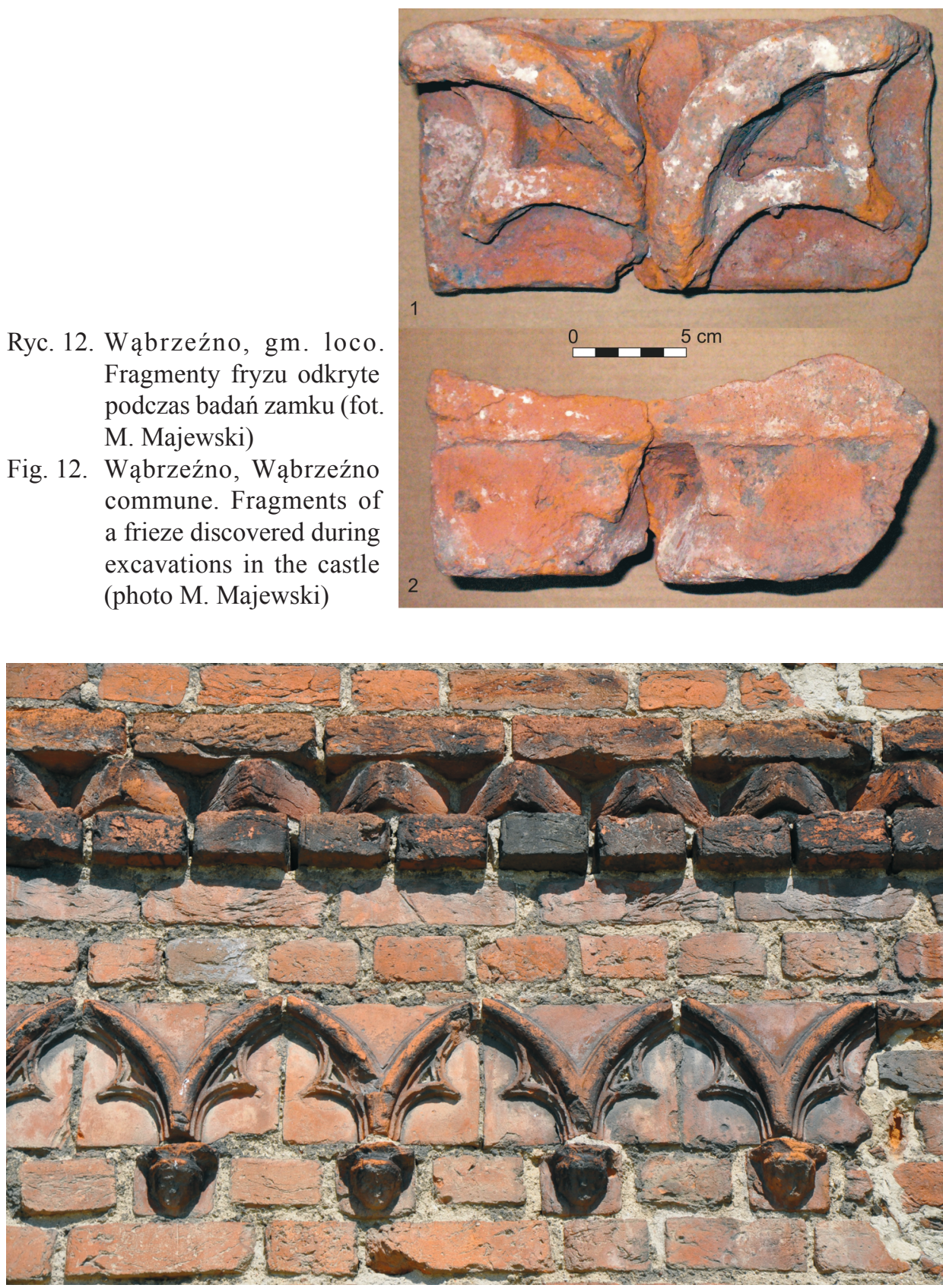

Ryc. 13. Radzyń Chełmiński, gm. loco. Elewacja południowa, fryz przy bramie (fot. B. Wasik)

Fig. 13. Radzyń Chełmiński, Radzyń Chełmiński commune. South face, a frieze at the gate (photo B. Wasik) 
Interesującym elementem zabudowy zamku w Wąbrzeźnie jest również, odkryty w 2011 roku, fragment muru parchamu, który był jednocześnie licowaniem skarpy fosy zamkowej (ryc. 14). Analiza techniki, a zwłaszcza formy tego muru wskazuje na najlepsze wzorce budownictwa zakonu krzyżackiego (Wiewióra 2012b; 2012c). Przykład podobnych murów oporowych znamy z zamków w Radzyniu Chełmińskim i Bierzgłowie (Arszyński 1959, s. 18, 36).

Kolejnym obiektem do tej pory niebadanym jest zamek w Kowalewie Pomorskim. W przeciwieństwie do pozostałych budowli, nieznany jest plan, nie zachowały się źródła ikonograficzne, a funkcjonujący w literaturze szkic C. Steinbrechta stanowi tylko jego bardziej lub mniej poprawną wizję (ryc. 15) ${ }^{8}$. Obiekt ten wzniesiono głównie z dużych kamieni narzutowych. Podobnie jak w przypadku wielu innych zamków przypuszczano, że powstał on w miejscu starszego grodu. Obok C. Steinbrechta, który jest autorem planu zamku, wśród badaczy zajmujących się tym obiektem był również Johannes Heise (1887, s. 183-187; por. też Steinbrecht 1888, s. 26-27). Po drugiej wojnie światowej informacje na temat warowni znalazły się w pracy Bohdana Guerquina (1984, s. 174) oraz w „Katalogu Zabytków Sztuki w Polsce" (1973, z. 6, s. 34-35). Więcej uwagi poświęcił dziejom zamku Bogumił Rogalski (1986, s. 57-95), który nieco zmodyfikował jego rzut, nie mając jednak ku temu żadnych realnych i wartościowych podstaw (Pabian, Rozynkowski 1997, s. 59-64; Haftka 1999, s. 135-139; Antkowiak, Lamparski 2000, s. 47-49). Wspominany już T. Torbus obiekt w Kowalewie umieścił w grupie wczesnych zamków regularnych z terenu ziemi chełmińskiej, obok Papowa, Lipienka, Rogoźna i Golubia (Torbus 1998, s. 132-137, 637-641).

Badania archeologiczne zamku w Kowalewie Pomorskim, rozpoczęte w 2013 roku, miały przede wszystkim poszerzyć wiedzę na temat jego topografii i rozplanowania. W tym celu założono pięć wykopów w jednej linii, na osi północpołudnie, opierając je na przedłużeniu krótszego boku jedynego, zachowanego do dzisiaj, elementu zabudowy zamku - filaru bądź wieży gdaniska, znajdującej się w odległości kilkudziesięciu metrów na południe od wzgórza zamkowego. Dodatkowo założono jeszcze dwa wykopy na osi wschód-zachód, aby w ten sposób określić zasięg murów zamkowych i jego wymiary (ryc. 16). W wyniku badań wykopaliskowych odsłonięto fragment bruku wyznaczającego zasięg dziedzińca i jego poziom (ryc. 17). Niestety, nie udało się w sposób bezsporny określić z jakiego okresu pochodzi, ponieważ znaleziona pod brukiem ceramika naczyniowa datowana jest w szerokich ramach na XIV-XVI stulecia i sugeruje, że może to być wczesnonowożytny poziom użytkowy, a nie późnośredniowieczny. Udało się natomiast odsłonić w dwóch wykopach negatywy po murach kurtyn skrzydła południowego, obie zostały jednak całkowicie rozebrane (ryc. 18). Po północnej stronie wzgórza zarejestrowano również dwa odcinki ław fundamentowych, które świadczą o tym, że niektóre partie ław fundamentowych zamku mogły zachować

${ }^{8}$ Oryginalna dokumentacja $\mathrm{z}$ tych oględzin nie zachowała się. 


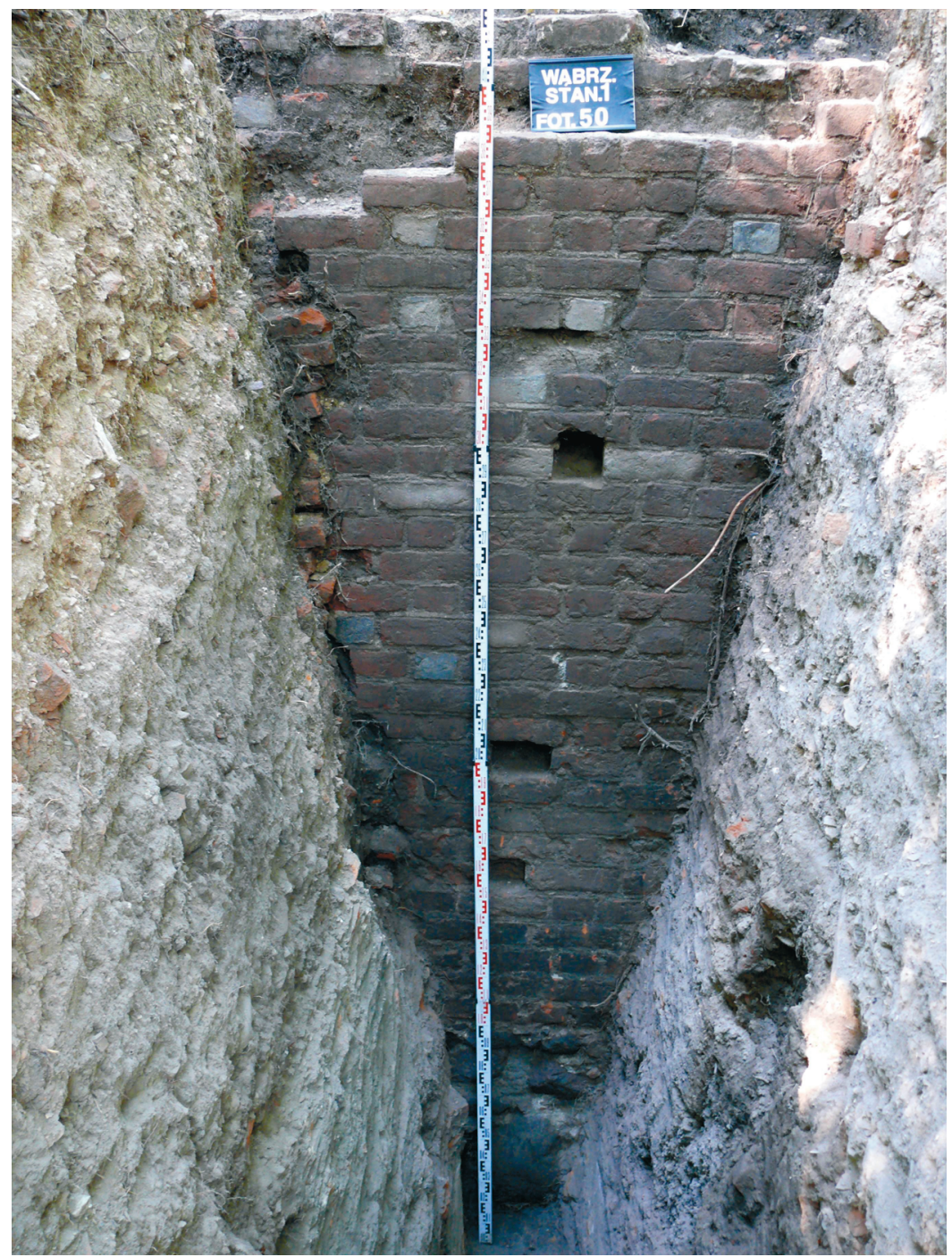

Ryc. 14. Wąbrzeźno, gm. loco. Lico muru parchamu na zamku (fot. M. Wiewióra)

Fig. 14. Wąbrzeźno, Wąbrzeźno commune. Face of the parcham wall in the castle (photo M. Wiewióra)

się do dziś i posłużyć do pełnej rekonstrukcji jego planu. Nie wiemy jeszcze jaką funkcję pełniło pomieszczenie położone w tej części zespołu zamkowego.

Obecnie trudno powiedzieć, czy zamek w Kowalewie Pomorskim należy faktycznie do grupy regularnych budowli konwentualnych; miejmy nadzieję, że przyszłe sezony badawcze pozwolą na rozstrzygnięcie tej kwestii. Interesujących danych dostarczyły natomiast obserwacje znalezionego podczas badań detalu 


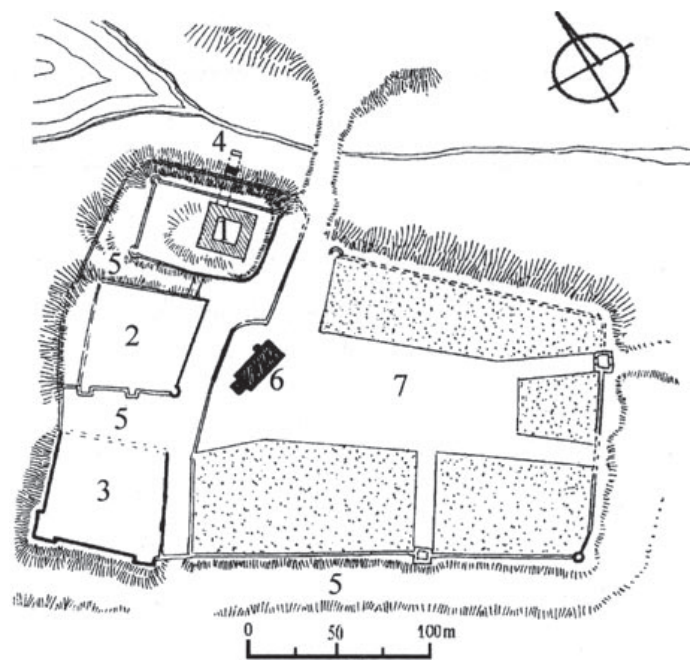

Ryc. 15. Kowalewo Pomorskie, gm. loco. Rekonstrukcja zamku górnego z przedzamczami (wg Steinbrecht 1888)

Fig. 15. Kowalewo Pomorskie, Kowalewo Pomorskie commune. Reconstruction of the upper castle with forebuildings (after Steinbrecht 1888)

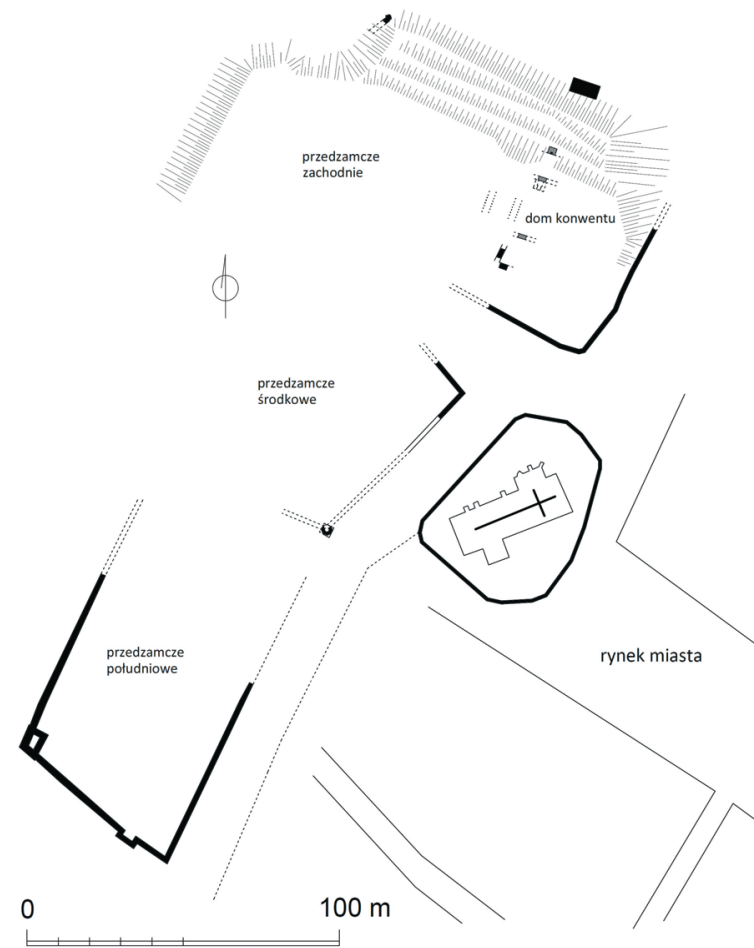

Ryc. 16. Kowalewo Pomorskie, gm. loco. Rzut poziomy pozostałości zamku i przedzamczy z lokalizacją wykopów w 2013 roku (oprac. B. Wasik)

Fig. 16. Kowalewo Pomorskie, Kowalewo Pomorskie commune. Plan of the remains of the castle and forebuildings with the location of trenches from 2013 (prepared by B. Wasik) 


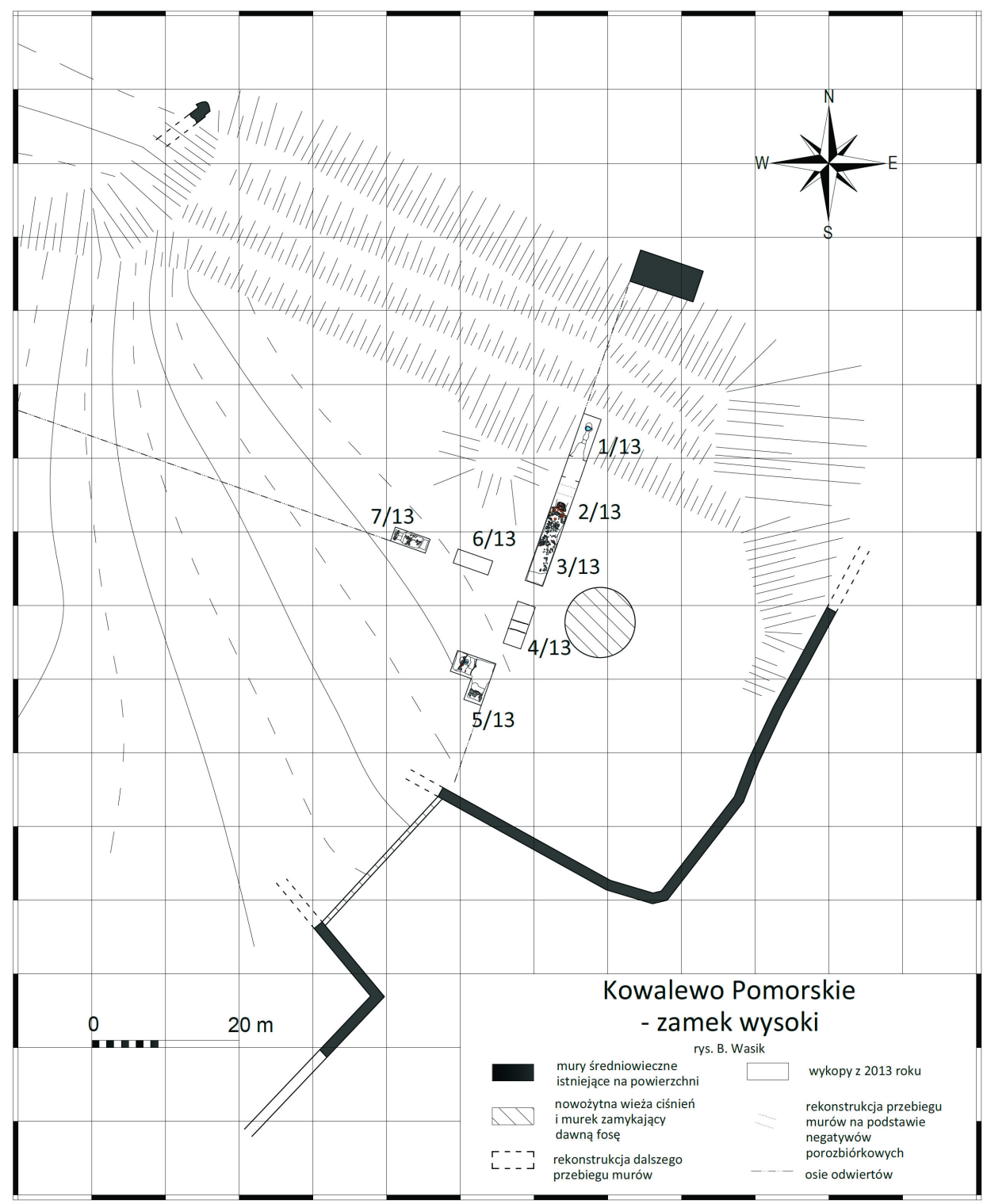

Ryc. 17. Kowalewo Pomorskie, gm. loco. Lokalizacja wykopów badawczych z 2013 roku (oprac. B. Wasik)

Fig. 17. Kowalewo Pomorskie, Kowalewo Pomorskie commune. Location of research trenches from 2013 (prepared by B. Wasik) 


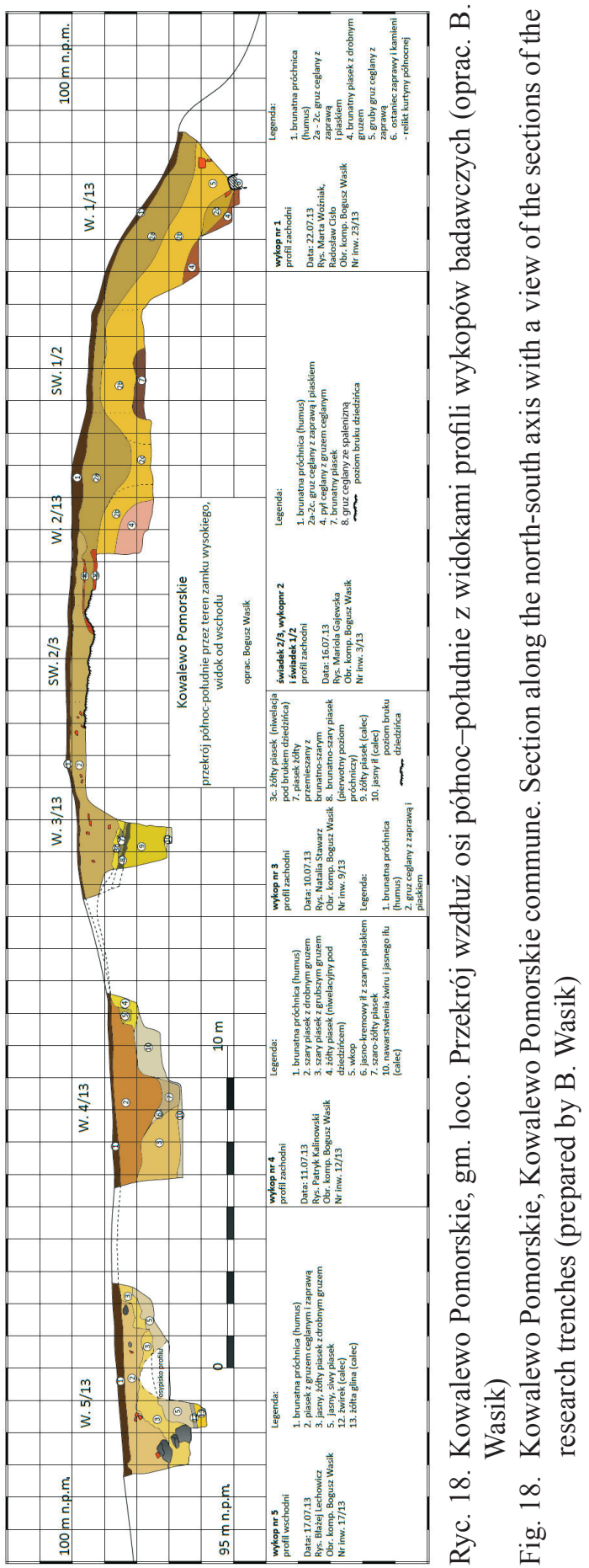


architektonicznego. Jak na obiekt tak zniszczony odkryto liczny zespół cegieł profilowanych - ościeżnicowych, sklepiennych, gzymsowych, oraz dachówek i elementów należących być może do wystroju okien - maswerku. Wstępne analizy detali wskazują, że z pewnością nie pochodzą one z wczesnych etapów budowy zamków ceglanych na ziemi chełmińskiej, bardziej przypominają zaś detal jaki obserwujemy na zamkach w Golubiu-Dobrzyniu czy Radzyniu Chełmińskim. Trudno ocenić, czy jest to jednocześnie dowód na to, że budowa obiektu w Kowalewie Pomorskim przeciągnęła się znacznie poza koniec XIII stulecia i zakończyła w XIV wieku. Pewne jest natomiast, że cegły te pasują do detalu użytego do budowy pobliskiego kościoła w Kowalewie Pomorskim, który był wzniesiony prawdopodobnie w tym samym okresie - w latach 1286-1300 i z pewnością modernizowany w XIV stuleciu. Ale podobnie, jak w przypadku zamku jest to tylko data umowna i nie mamy obecnie bliższych informacji na ten temat (Danielewicz 1986).

Na podstawie przytoczonych wyżej wyników analiz oraz w przyjętym programie badawczym zakładamy, że początkowe etapy wznoszenia murowanych budowli obronnych przebiegały nierównomiernie i uzależnione były od szeregu czynników związanych z uwarunkowaniami lokalnymi - topografią i środowiskiem (forma, kształt i układ przestrzenny obiektu) oraz sytuacją polityczną, a nie tylko z treściami płynącymi ze statutów czy ustaw zakonnych określających charakter i funkcję pomieszczeń niezbędnych do realizacji podstawowych funkcji przez nie pełnionych. Analizując charakter i zasięg prac budowlanych zamków regularnych w Papowie Biskupim i Radzyniu Chełmińskim oraz wcześniejszych zamków należących do obiektów nieregularnych - na przykład w Grudziądzu, okazuje się, że te ostatnie powstawały przy użyciu znacznie mniejszych środków i sił niż pierwsze wymienione. $Z$ pewnością wynikało to $z$ odmiennej sytuacji politycznej, zwłaszcza w strefie nadgranicznej, ustabilizowanej wówczas, gdy powstawały zamki regularne. Świadczy o tym chociażby stopień zaangażowania i zasięg wstępnych prac przygotowawczych (prac ziemnych), które wymagały znacznego udziału ludzi i środków finansowych. Poza tym:

- prace budowlane na wielu zamkach realizowane były prawdopodobnie później niż do tej pory zakładano (faza murowana);

- nie we wszystkich przypadkach istniało osadnictwo wcześniejsze, lub brakuje przekonujących dowodów potwierdzających taką tezę w dotychczasowych wynikach badań;

- forma regularnych założeń obronnych na planie zbliżonym do kwadratu (tzw. zamki konwentualne) mogła pojawić się i rozpowszechnić w ostatnich latach XIII lub w początkach XIV wieku, na co wskazują wyniki ostatnich badań nad zamkami na ziemi chełmińskiej. 


\section{Literatura}

Antkowiak W., Lamparski P.

2000 Zamki i strażnice krzyżackie ziemi chetmińskiej, Toruń. Arszyński M.

1958 Ruiny zamku w Papowie Biskupim, pow. Chełmno, woj. bydgoskie - dokumentacja historyczna do prac konserwatorskich, maszynopis w archiwum Wojewódzkiego Urzędu Ochrony Zabytków w Toruniu, Toruń.

1959 Zamek krzyżacki w Bierzgłowie, powiat Toruń, województwo bydgoskie. Dokumentacja historyczna do prac konserwatorskich w zakresie architektury opracowana do użytku PP Pracownie Konserwacji Zabytków, maszynopis w archiwum Wojewódzkiego Urzędu Ochrony Zabytków w Toruniu, Toruń.

1961 Z badań nad zamkiem pokrzyżackim w Radzynie, Rocznik Grudziądzki, t. 2, s. 39-77.

1995 Budownictwo warowne zakonu krzyżackiego w Prusach (1230-1450), Toruń. Atlas historyczny

1997 Atlas historyczny miast polskich, t. 1: Prusy Królewskie i Warmia, z. 4: Grudziądz, red. A. Czacharowski, oprac. historyczne W. Sieradzan, oprac. kartograficzne Z. Kozieł, Torun.

Baciński J.

2004 Zamek Biskupów Chetmińskich w Wąbrzeźnie, Wąbrzeźno.

Bieniak J.

1970 Studia z dziejów ziemi chetmińskiej w okresie piastowskim, Rocznik Grudziądzki, t. 5/6, Grudziądz, s. 5-69.

Boguwolski R., Kola A.

1972 Sprawozdanie z archeologicznych badań wiertniczych przeprowadzonych na obszarze miasta Grudziadza w okresie 19-26.IV.1972 roku, Informator Muzeum w Grudziądzu, R. 13, nr 2, 54-64.

Bokiniec E.

2012 Młodszy okres przedrzymski i okres wpływów rzymskich, [w:] Zamek w Grudziadzu, s. 171-173.

Chudziak W.

1996 Quondam castra w świetle badań wczesnośredniowiecznych grodzisk ziemi chetmińskiej, Archaeologia Historica Polona, t. 3, s. 25-34.

Chudziak W., Kurzyńska M.

2012 Wczesne średniowiecze, [w:] Zamek w Grudziadzu, s. 173-190.

Clasen K. H.

1927 Die mittelalteriche Kunst im Gebiete des Deutschordensstaates Preussen,

t. 1: Die Burgbauten, Königsberg.

Danielewicz J.

1986 Dzieje Kowalewa Pomorskiego, Bydgoszcz. 
Durdík T.

1994 Kastellburgen des 13. Jahrhunderts in Mitteleuropa, Praha.

Dusburg

2004 Piotr z Dusburga. Kronika ziemi pruskiej, thum. S. Wyszomirski, wstęp i komentarz J. Wenta, Torun.

Froelich X.

1884-1885 Geschichte des Graudenzer Kreises, t. 1-2, Danzing.

Gackowski J.

2012 Wczesna epoka żelaza, [w:] Zamek w Grudziądzu, s. 159-171.

Guerquin B.

1984 Zamki w Polsce, Warszawa.

Haftka M.

1999 Zamki krzyżackie w Polsce, Malbork.

Heise J.

1887 Die Bau- und Kunstdenkmäler der Provinz Westpreussen - des Kreis Kulm, z. 5, Danzig.

1894 Die Bau- und Kunstdenkmäler der Provinz Westpreussen - des Kreis Graudenz, z. 9, Danzig.

Herrmann Ch.

2007 Mittelalterliche Architektur im Preussenland. Untersuchungen zur Frage der Kunstlandschaft und Geographie, Petersberg-Olsztyn.

Jacobi H.

1996 Die Ausgrabungsergebnisse der Deutschordensburgen Graudenz und Roggenhausen. Ein Beitrag zur baugeschichtlichen Entwicklung der Ordensburgen, oprac. U. Arnold, Braubach.

Janikowski J.

1963a Dziennik wykopalisk, rękopis w archiwum Wojewódzkiego Urzędu Ochrony Zabytków w Toruniu, Toruń.

1963b Sprawozdanie z prac wykopaliskowych na przedzamczu krzyżackim w Radzyniu Chełmińskim, maszynopis w archiwum Wojewódzkiego Urzędu Ochrony Zabytków w Toruniu, Toruń.

Jasiński T.

1992 Okoliczności nadania ziemi chetmińskiej Krzyżakom w 1228 roku w świetle dokumentu łowickiego, [w:] Balticum. Studia z dziejów polityki, gospodarki i kultury XII-XVII wieku. Ofiarowane Marianowi Biskupowi w siedemdziesiatą rocznicę urodzin, red. Z. H. Nowak, Toruń, s. 151-163.

Jóźwiak S.

1997 Powstanie i rozwój struktury administracyjno-terytorialnej zakonu krzyżackiego na Kujawach $i$ w ziemi chetmińskiej w latach 1246-1343, Torun.

Jóźwiak S., Trupinda J.

2011 Organizacja życia na zamku krzyżackim w Malborku w czasach wielkich mistrzów (1309-1457), Malbork.

2012 Krzyżackie zamki komturskie w Prusach. Topografia i uktad przestrzenny na podstawie średniowiecznych źródet pisanych, Torun. 
Kajzer L., Kołodziejski S., Salm J.

2001 Leksykon zamków w Polsce, Warszawa.

Katalog

1973 Katalog zabytków sztuki w Polsce, t. 11, z. 6, red. T. Chrzanowski, M. Kornecki, Warszawa.

Kordowski J., Tyszkowski S., Bienias D.

2012 Budowa geologiczna i przekształcenia rzeźby Góry Zamkowej i jej otoczenia, [w:] Zamek w Grudziądzu, s. 29-47.

Majewski M.

2010 Detal architektoniczny z zamku biskupów w Wąbrzeźnie, maszynopis w Instytucie Archeologii UMK, Toruń.

Mikołajczyk G.

1960 Wyniki prac archeologicznych na zamku w Radzyniu Chetmińskim w 1957 roku, Ochrona Zabytków, nr 1-4, s. 89-98.

Momot A.

2012 Badania archeologiczno-achitektoniczne zamku krzyżackiego w Papowie Biskupim w roku 2012, [w:] Sprawozdanie z badań archeologiczno-architektonicznych zamku w Papowie Biskupim w 2012 r., maszynopis w archiwum

Mroczko T. Wojewódzkiego Urzędu Ochrony Zabytków w Toruniu, Toruń.

1980 Architektura gotycka na ziemi chetmińskiej, Warszawa.

Pabian A., Rozynkowski W.

1997 Zamki krzyżackie na ziemi chetmińskiej, Toruń.

Pluskowski A.

2012 The archaeology of the Prussian Crusades: holy war and colonisation, London.

Poliński D.

2003 Gród czy zamek? Z badań nad najwcześniejszymi krzyżackimi obiektami obronnymi w ziemi chetmińskiej, Archaeologia Historica Polona, t. 15/1, s. 181-196.

2007a Chetmińskie” warownie Zakonu na pograniczu krzyżacko-pruskim i krzyżacko-polskim, [w:] Pogranicze polsko-pruskie i krzyżackie, t. 2, red. K. Grążawski, Włocławek-Brodnica, s. 155-178.

$2007 \mathrm{~b}$ Krzyżackie warownie drewniano-ziemne $w$ świetle badań archeologicznych, Archaeologia Historica Polona, t.17, s. 241-257.

Powierski J.

1973 Studia nad strukturą administracyjno-terytorialna ziemi chetmińskiej i michałowskiej w okresie piastowskim, Bydgoskie Towarzystwo Naukowe, Prace Wydziału Nauk Humanistycznych, seria C, nr 13, Prace Komisji Historii 9, s. 3-86.

PU

1881-1882 Pommerelisches Urkundenbuch, t. 1, wyd. M. Perlbach, Danzig. 
PUB

1882 Preussisches Urkundenbuch, t. 1/1, nr 41, wyd. A. Philippi, C. Woelky, Königsberg.

Rogalski B.

1986 Dzieje miasta do XVIII w. oraz rozwój przestrzenny, [w:] Dzieje Kowalewa Pomorskiego, red. J. Danielewicz, Bydgoszcz, s. 57-95.

Rozynkowski W.

1995 Średniowieczne dzieje Papowa Biskupiego, Papowo Biskupie.

2002 Zamek krzyżacki w Papowie Biskupim-klasztor, warownia, ośrodek administracyjny i gospodarczy, [w:] Zamki i przestrzeń społeczna w Europie Środkowej i Wschodniej, red. M. Antoniewicz, Warszawa, s. 339-352.

Schmid B.

1929 Zur Baugeschichte der Ordens- und Bischofsschlösser in Preußen. Graudenz, Zeitschrift des Westpreußischen Geschichtsvereins, t. 69, s. 55-68.

1938 Die Burgen des Deutschen Ritterordens in Preußen, Berlin.

1939 Bau- und Kunstdenkmäler der Ordenszeit in Preussen, t. 1: Kulmerland und Pomerellen, Marienburg.

1940 Die Burgen des deutschen Ritterordens in Preußen, Ergänzungsheft, t. 2, Berlin.

Sławiński I.

1957 Zamek krzyżacki w Radzyniu. Inwentaryzacja, maszynopis w archiwum Wojewódzkiego Urzędu Ochrony Zabytków w Toruniu, Toruń.

1959 Opis techniczny do inwentaryzacji zamku krzyżackiego w Papowie Biskupim, pow. Chełmno, Toruń, maszynopis w archiwum Wojewódzkiego Urzędu Ochrony Zabytków w Toruniu, Toruń.

1962 Inwentaryzacja odkrywek architektonicznych, maszynopis w archiwum Wojewódzkiego Urzędu Ochrony Zabytków w Toruniu, Toruń.

1964 Inwentaryzacja klatki schodowej zamku w Radzyniu Chełminskim, maszynopis w archiwum Wojewódzkiego Urzędu Ochrony Zabytków w Toruniu, Toruń.

1965 Inwentaryzacja odkrywek architektonicznych, maszynopis w archiwum Wojewódzkiego Urzędu Ochrony Zabytków w Toruniu, Toruń.

1967 Inwentaryzacja architektura, zamek w Radzyniu, maszynopis w archiwum Wojewódzkiego Urzędu Ochrony Zabytków w Toruniu, Torun.

Sławiński I., Cabała A.

1966 Inwentaryzacja detali architektonicznych. Zamek w Pokrzywnie-zamek wysoki, średni, przedzamcze, pow. Grudziądz, woj. bydgoskie, Toruń, nr 324, maszynopis w archiwum Wojewódzkiego Urzędu Ochrony Zabytków w Toruniu, Toruń.

Sławiński I., Czaplińska M., Majewski P.

1984 Inwentaryzacja budowlano-konserwatorska odkrywek archeologicznych $\mathrm{z}$ rozwarstwieniem. Mury obronne przedzamcza, przedmurze z gdaniskiem, maszynopis w archiwum Wojewódzkiego Urzędu Ochrony Zabytków w Toruniu, Toruń. 
Steinbrecht C.

1888 Baukunst des Deutschen Ritterordens in Preussen, t. 2: Preussen zur Zeit der Landmeister, Berlin.

Szymański K.

1960 Dzieje zamku grudziądzkiego, Rocznik Grudziądzki, t. 1, s. 73-104.

Torbus T.

1998 Die Konventsburgen in Deutschordensland Preussen, München.

2004 Anmerkungen zu den Verzieungsformen aus Glasur und schwarz gebranten Köpfen an den Deutschordensburgen - eine Bestandsaufnahme. Klassifizierung und der Versuch, ihre Herkunft zu bestimmen, [w:] Castrum Bene: Castle and church, nr 5, red. L. Kajzer, H. Paner, Gdańsk, s. 219-238.

Wasik B.

2012 Badania architektoniczne zamku w Papowie Biskupim przeprowadzone w 2012 roku, [w:] Sprawozdanie z badań archeologiczno-architektonicznych zamku w Papowie Biskupim w 2012 r., maszynopis w archiwum Wojewódzkiego Urzędu Ochrony Zabytków w Toruniu, Toruń.

2013 Dzieje budowy i architektura zamkuw Papowie Biskupim na ziemi chełmińskiej w świetle ostatnich badań, maszynopis w Instytucie Archeologii UMK, Torun.

Wiewióra M.

2007 Badania archeologiczno-architektoniczne średniowiecznego zamku w Papowie Biskupim w ziemi chetmińskiej, Archaeologia Historia Polona, t. 17, s. 293-305.

2005 Wyniki badań archeologiczno-architektonicznych zamku w Papowie w 2005 r., maszynopis w Instytucie Archeologii UMK, Toruń.

2006 Wyniki badań archeologiczno-architektonicznych zamku w Papowie w 2006 r., maszynopis w Instytucie Archeologii UMK, Torun.

2007 Wyniki badań archeologiczno-architektonicznych zamku w Papowie w 2007 r., maszynopis w Instytucie Archeologii UMK, Toruń.

2008 Wyniki badań archeologiczno-architektonicznych zamku w Papowie w 2008 r., maszynopis w Instytucie Archeologii UMK, Toruń.

2012a Próba rekonstrukcji etapów budowy i układu przestrzennego zamku, [w:] Zamek w Grudziadzu, s. 359-378.

2012b Nowe źródła do dziejów zamku biskupów w Wąbrzeźnie, Rocznik Grudziądzki, t. 20, s. 11-30.

2012c Opracowanie wyników badań archeologiczno-architektonicznych na zamku biskupim w Wąbrzeźnie w 2011 roku, maszynopis w Instytucie Archeologii UMK, Toruń.

Zamek w Grudziądzu

2012 Zamek $w$ Grudziądzu w świetle badań archeologiczno-architektonicznych. Studia i materiaty, red. M. Wiewióra, Toruń.

Zimnowoda-Krajewska B.

2012 Analiza źródet architektonicznych, [w:] Zamek w Grudziądzu, s. 127-158. 


\section{THE LONG $13^{\text {TH }}$ CENTURY - THE BEGINNINGS OF THE TEUTONIC ORDER DEFENSIVE MASONRY ARCHITECTURE IN CHEŁMNO LAND IN LIGHT OF RECENT RESEARCH}

Summary

Castles built by the Teutonic Knights in Chełmno Land became one of the most characteristic features of the landscape. They served different functions and realized political, military, economic and propaganda goals. They became visible evidence of a well-organized state. For many years attempts to compile a comprehensive view of this area have been undertaken.

This article presents a brief summary of research undertaken in 2005 by the Department of Archaeology of Architecture, the Institute of Archaeology of the Nicolaus Copernicus University in Toruń on castles in Papowo Biskupie, Grudziądz, Radzyń Chełmiński, Wąbrzeźno and Kowalewo Pomorskie. Its goal is to attempt to answer fundamental questions related to the origins of the Teutonic Order defensive brick architecture in Chełmno Land. It concerns the details of construction, topography, the spatial layout of castles, determination of the beginning of construction activity as well as the origins and layout of the oldest fortresses.

Based on results of analyses and those of the research programme, it was assumed that the initial stages of the erection of defensive masonry buildings proceeded unevenly and was dependent on a number of factors related to local conditions - the topography and environment (type, shape and spatial layout of a given object) as well as the political situation, and not only on the content of the Order's statutes or regulations defining the nature and function of spaces needed for the realization of their basic functions. Analyzing the nature and extent of the construction work of regular castles (Papowo Biskupie and Radzyń Chełmiński) and earlier castles belonging to irregular objects (e.g. Grudziądz). It is evident that the latter were built by much less means and effort than the former. Certainly, this was due to the different political situation, especially in the border zone, which then stabilized when the regular castles were erected. This effort is evidenced by the degree of involvement and extent of the initial preparatory works (earthworks), which required a significant participation of men and financial resources. Moreover, it was established that construction work on many castles were probably carried out later than was previously assumed (masonry phase). Nor in all cases was there earlier settlements and there is no convincing evidence for such an assumption in the existing research results. The form of regular defensive edifices with a square-like plan (the so-called conventual castles) could have occurred and spread in the last years of the $13^{\text {th }}$ or early $14^{\text {th }}$ century as indicated by the results of recent research on the castles in Chełmno Land. 